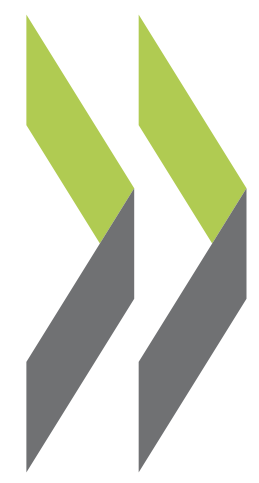

OECD Economics Department Working Papers No. 1038

The Efficiency and Equity of the Tax and Transfer Balázs Égert System in France 
Organisation de Coopération et de Développement Économiques

Organisation for Economic Co-operation and Development

27-Mar-2013

ECONOMICS DEPARTMENT

English - Or. English

THE EFFICIENCY AND EQUITY OF THE TAX AND TRANSFER SYSTEM IN FRANCE

ECONOMICS DEPARTMENT WORKING PAPER No. 1038

By Balázs Égert

All OECD Economics Department Working Papers are available through OECD's Internet website at www.oecd.org/eco/Workingpapers

JT03337125

Complete document available on OLIS in its original format

This document and any map included herein are without prejudice to the status of or sovereignty over any territory, to the delimitation of international frontiers and boundaries and to the name of any territory, city or area. 


\section{ABSTRACT/RESUME}

\section{The efficiency and equity of the tax and transfer system in France}

Taxes and cash transfers reduce income inequality more in France than elsewhere in the OECD, because of the large size of the flows involved. But the system is complex overall. Its effectiveness could be enhanced in many ways, for example so as to achieve the same amount of redistribution at lower cost. The French tax code should be simplified and changed less frequently. High statutory rates are coupled with a wide range of effective tax rates resulting from a multitude of tax expenditures. There is a need for base broadening combined with lower rates throughout the system, including VAT. The tax wedge on labour is high, except at the bottom of the wage distribution, which can reduce worker participation and job offers. Greater neutrality both across different capital asset classes but also within specific taxes, and shifting taxes from labour and capital inputs to environmental and property taxes would improve economic outcomes. Likewise, the system of social and family benefits should be simplified to enhance transparency and consistency. Eliminating schemes that let people leave the labour market early, abolishing the pension privileges of specific occupational groups and internalising the costs of survivors' pension benefits would increase fairness while at the same time generating savings. Better labour-market performance would result from increasing job-search incentives and shortening the parental leave allowance. This Working Paper relates to the 2013 OECD Economic Survey of France (www.oecd.org/eco/surveys/France).

JEL classification codes: D30; H20; H30; H50; H55; H70; J20; J30

Keywords: taxation; cash transfers; income inequality; redistribution

$* * * * *$

\section{Efficacité et équité du système de prélèvements et de transferts en France}

Les impôts et les transferts en espèces réduisent en France les inégalités de revenu plus que dans beaucoup d'autres pays de l'OCDE en raison de la taille importante des flux concernés. Mais le système est complexe dans son ensemble. Son efficacité pourrait être améliorée à bien des égards, par exemple pour atteindre le même degré de redistribution à moindre coût. Le code des impôts devrait être simplifié et moins fréquemment modifié. Les taux statutaires élevés vont de pair avec un large éventail de taux d'imposition effectifs résultant d'une multitude de niches fiscales et sociales. Il est nécessaire d'élargir l'assiette fiscale, y compris pour la TVA, et de baisser les taux dans l'ensemble du système. Le coin fiscal sur les revenus du travail est élevé sauf dans le bas de la distribution des salaires, ce qui peut réduire la participation au marché du travail ainsi que les offres d'emploi. Une plus grande neutralité fiscale à l'intérieur et entre les différentes catégories d'actifs, et le déplacement des prélèvements sur le travail et le capital vers les taxes environnementales et les taxes sur la propriété immobilière permettraient d'améliorer les performances économiques. De la même façon, le système de prestations sociales devrait être simplifié pour gagner en transparence et en cohérence. La suppression des dispositifs permettant les sorties précoces du marché du travail, l'élimination des régimes spéciaux de retraite et l'internalisation du coût des pensions de réversion augmenteraient l'équité tout en générant des économies. Les performances du marché du travail pourraient être améliorées en augmentant les incitations à la recherche d'emploi et en raccourcissant l'allocation de congé parental. Ce Document de travail se rapporte à l'Étude économique de l'OCDE de la France 2013 (www.oecd.org/eco/etudes/France).

Classification JEL : D30 ; H20 ; H30 ; H50 ; H55 ; H70 ; J20 ; J30

Mots clefs : fiscalité ; transferts en espèce ; inégalité de revenue ; redistribution

(C) OECD (2013)

You can copy, download or print OECD content for your own use, and you can include excerpts from OECD publications, databases and multimedia products in your own documents, presentations, blogs, websites and teaching materials, provided that suitable acknowledgment of OECD as source and copyright owner is given. All requests for commercial use and translation rights should be submitted torights@oecd.org. 


\section{Table of contents}

The efficiency and equity of the tax and transfer system in France................................................. 5

Income inequality is relatively low, thanks to redistribution, and has been stable over time .................... 5

The French tax system is complex, changes frequently and induces serious distortions .......................... 8

The taxation of labour is heavy despite substantial targeted measures .................................................. 9

Joint family income taxation may discourage female labour force participation..................................... 13

Incentives for older workers to keep working can be further improved................................................ 13

The mobility of high-income earners will limit the revenue yield of raising the top marginal tax rate.... 14

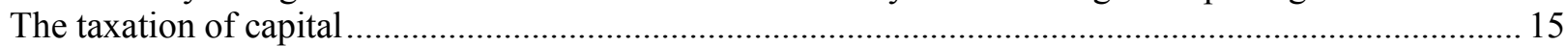

Effective marginal tax rates on capital income vary substantially ................................................. 15

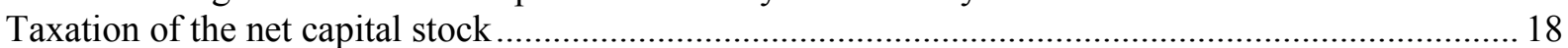

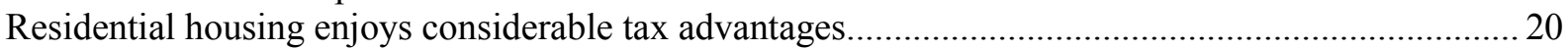

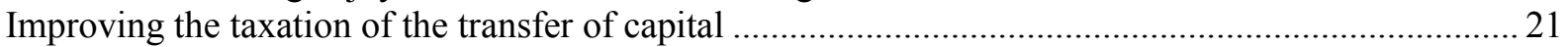

Reduced VAT rates are an inefficient way to redistribute income........................................................ 22

A large dispersion of implicit carbon prices but good progress in internalising local pollution............... 23

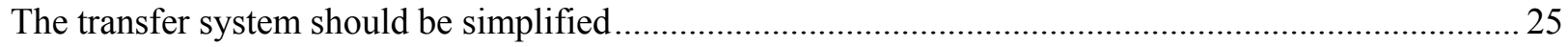

Conditionality of unemployment benefits should be strengthened ....................................................... 27

Social transfers should be focused on getting beneficiaries into jobs .....................................................2 29

Disability benefits are a potential channel of benefit substitution............................................................ 30

Family benefits are tilted towards those having at least three children............................................... 31

The design of the parental leave allowance may push low-skill mothers into an inactivity trap .............. 32

Housing subsidies should be better integrated with the rest of the transfer system ................................. 33

Old-age pension complexity should be reduced to facilitate necessary systemic reforms ....................... 34

Survivors' pensions lower female participation and discriminate against private-sector pensioners and

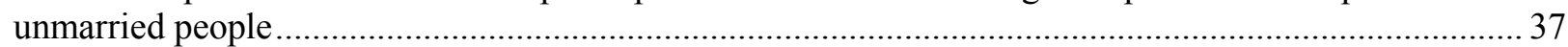

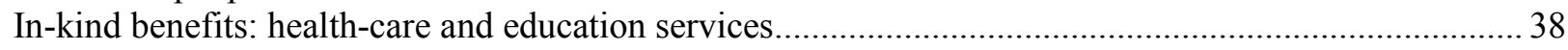

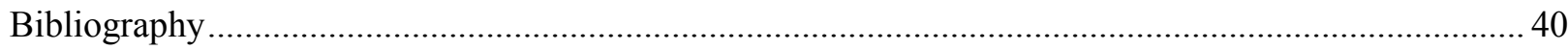

\section{Boxes}

1. From individual wage dispersion to income inequality at the household level............................. 6

2. Recommendations for improving the efficiency and equity of tax and transfer policies ............... 39

\section{Tables}

1. Tax wedge in $\%$ of labour costs for different wage levels and household types, $2011 \ldots \ldots \ldots \ldots \ldots . . . .11$

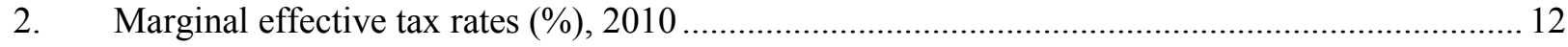

3. Effective top marginal tax rates on real returns of different asset classes, 2011 .......................... 17

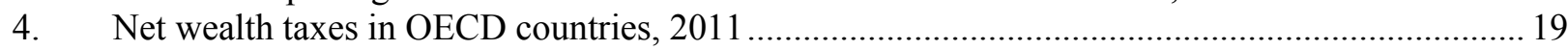




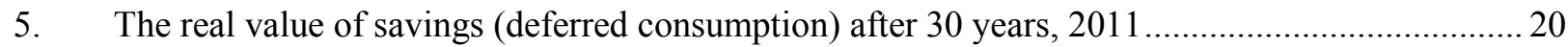

6. Top marginal rates on gifts and bequests in OECD countries, 2011 ......................................... 22

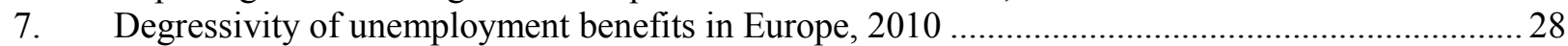

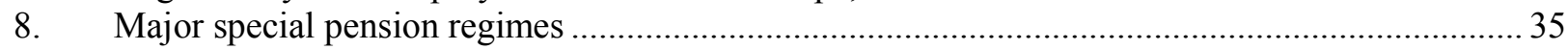

\section{Figures}

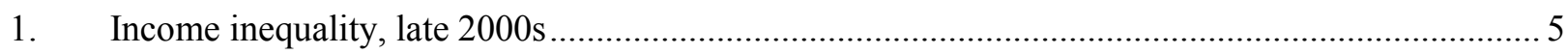

2. The level and evolution of the share of top income earners in total income ................................. 7

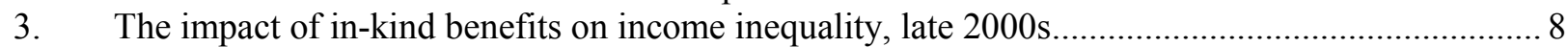

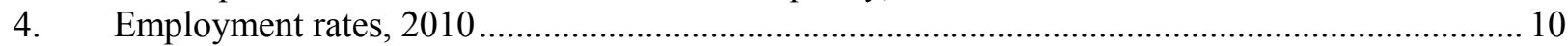

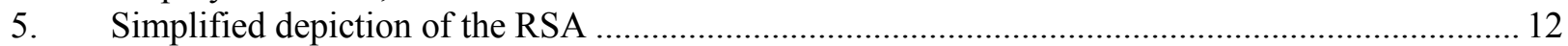

6. The dispersion of top marginal effective tax rates across different asset classes, $2011 \ldots \ldots \ldots \ldots \ldots . . . .16$

7. Corporate income tax (CIT) rates and revenue from those taxes as a $\%$ of total tax revenue........ 18

8. Carbon price dispersion across OECD countries and within France, 2010-Q4 ............................ 24

9. Dispersion of carbon abatement costs implied by indirect support schemes (feed-in tariffs, green

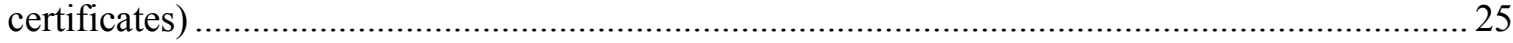

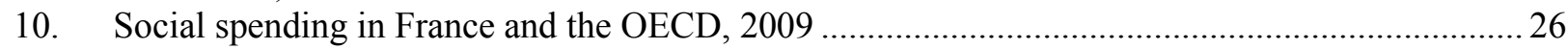

11. Active labour market policies and unemployment benefits .................................................... 27

12. Incapacity-related public spending and disability benefit receipt rates in OECD countries ............ 31

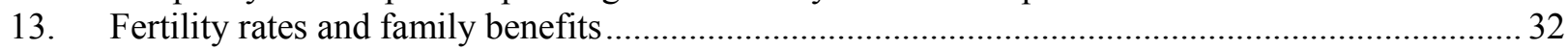

14. Enrolment rates in formal pre-school childcare institutions and the ratio of children to teaching

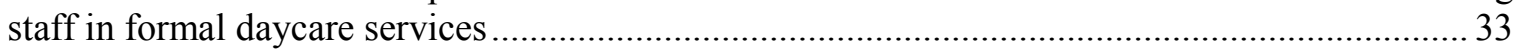

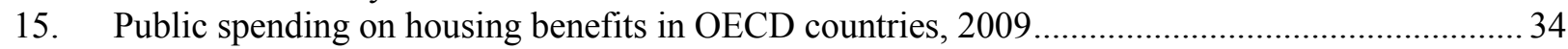

16. Old-age poverty rates in OECD countries, mid-2000s .............................................................. 37

The statistical data for Israel are supplied by and under the responsibility of the relevant Israeli authorities. The use of such data by the OECD is without prejudice to the status of the Golan Heights, East Jerusalem and Israeli settlements in the West Bank under the terms of international law. 
ECO/WKP(2013)30

\title{
The efficiency and equity of the tax and transfer system in France
}

\author{
By \\ Balázs Égert ${ }^{1}$
}

\section{Income inequality is relatively low, thanks to redistribution, and has been stable over time}

Inequality across French households' pre-tax-and-transfer market income has been among the highest in the OECD, measured for instance by the Gini coefficient (Figure 1). This can be mostly explained by France's low employment rate. The combination of low participation rates and high structural unemployment implies that an important fraction of the working-age population does not have any labour income. The dispersion in capital income (excluding imputed rents) plays a minor role in overall household market income dispersion: the contribution of capital income to income inequality in France is only about a quarter that of the average OECD country and is lower only in Central and Eastern European countries, Portugal and Korea (Hoeller et al., 2012; Koske et al., 2012).

Figure 1. Income inequality, late 2000s

Gini coefficients of household market and disposable income for working-age population

Per consumer unit
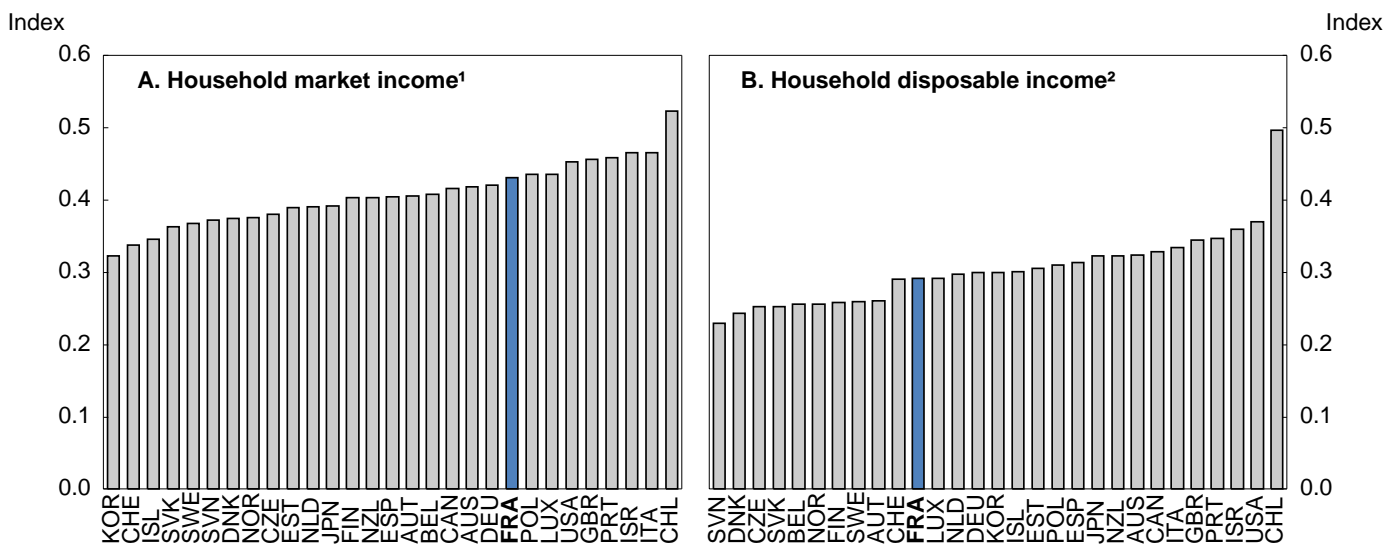

1. Before taxes and transfers.

2. After taxes and transfers.

Source: OECD, Income Distribution and Poverty database.

1. OECD Economics Department; e-mail: balazs.egert@oecd.org. This paper was prepared for the OECD Economic Survey of France published in March 2013 under the authority of the Economic and Development Review Committee. The author is thankful to Hervé Boulhol, Stéphane Carcillo, Andrew Dean, Robert Ford, Michael Förster, Peter Jarrett, Isabelle Joumard, Pierre Leblanc, Nobuko Miyachiyo, Valérie Paris, Mauro Pisu, Monika Quiesser, Anne Sonnet, Edward Whitehouse and French government officials for their valuable comments and suggestions. Special thanks are due to Patrizio Sicari for statistical research and Mee-Lan Frank and Maartje Michelson for technical preparation. 
Given the large size of the overall system, taxes and cash transfers reduce income inequality more in France than in most OECD countries (see Box 1). The Gini coefficient drops by around 14 percentage points after taxes and cash transfers are taken into account, whereas this decline is only 10 points in an average OECD country (see Figure 13 in the Assessment \& Recommendations). The sizable income redistribution reduces households' observed market income inequality from well above the OECD average to below it. The French statistical office, INSEE, estimates that, considering income that already incorporates pensions and unemployment benefits, which are largely insurance-based benefits, cash transfers account for two thirds of redistribution and taxes for the remaining third (Duval et al., 2012). Transfers related to family and housing and those aimed at maintaining a minimum income level represent $90 \%$ of redistribution effected by cash transfers. Sixty per cent of the redistribution generated by taxes comes from the personal income tax. Recent government measures, including a new top tax bracket and the integration of capital income into the personal income tax schedule, will increase the overall progressivity of the tax system.

\section{Box 1. From individual wage dispersion to income inequality at the household level}

The starting point for determining disposable income at the household level is labour income at the individual level: this may differ because of different wage rates, differences in hours worked or because of the lack of labour earnings due to unemployment or inactivity. The next step is labour income at the household level, which depends on family size and composition. Household income is expressed in terms of consumption per standardised unit, which helps compare living standards per person. Households also receive capital income, which in combination with labour income gives household market income. What income remains at a household's disposal (household disposable income) hinges upon the amounts received in cash transfers and paid in taxes. Households' adjusted disposable income is their income after taxes and transfers adjusted for their consumption of public services (OECD, 2011a; Hoeller et al., 2012).

\section{Measuring the degree of redistribution}

The degree of income redistribution at any point in time can be measured by comparing the Gini coefficient, a measure of income inequality, for household market income (income before taxes and transfers) and for household disposable income (income after taxes and transfers). A standard way is to compute Gini coefficients based on households ranked according to their market income (Gini before taxes and transfers) and disposable income (Gini after taxes and transfers). Gini coefficients calculated for total population include old-age pensioners. Based on this measure, public pension benefits will show up as pure redistribution between younger and older people, given that pensioners' market income will be zero, while their disposable income will equal pension benefits. If public pensions, including both contributions and benefits, are thought of as over-the-life cycle redistribution for individuals, including pensioners in the calculation may overstate overall income redistribution. One very rough way of attempting to correct for this problem is to calculate the Gini coefficient for market income using households re-ranked in accordance with disposable income. Nevertheless, public pension systems may contain strong instantaneous income redistribution in the presence of minimum pensions, unrelated to lifetime pension contributions, and generous special occupational pension schemes, or if the parameters of the system change over time. Another way of filtering out the effect of pension benefits is to calculate the Gini coefficient for the working-age population (15-64) alone. However, such Gini coefficients may not be fully comparable across countries if the average retirement age differs and thus the share of old-age pensioners in the population aged 15-64 years varies.

\section{How much income redistribution does the French tax and transfer system undertake?}

According to the dataset used in Joumard et al. (2012), in the mid-2000s income redistribution resulting from the tax and cash transfer system reduced the Gini coefficient (for working-age population) less than the OECD median. But the Gini coefficient was calculated by ranking households in accordance with their disposable income, including for the Gini coefficient on household market income. Yet the calculation for a new vintage of the data for the end-2000s shows a redistribution of 9 percentage points for France, against an OECD median of 7 percentage points. Income redistribution, obtained using household market income for households ranked by household market income, as used in this paper, was around 14 percentage points (the median Gini decline was around 11 percentage points), both in the mid- and late 2000s. Overall, income redistribution is higher in France than in many other OECD countries.

Source: Joumard, I., M. Pisu and D. Bloch (2012), "Less Income Inequality and More Growth - Are They Compatible? Part 3. Income Redistribution via Taxes and Transfers Across OECD Countries", OECD Economics Department Working Papers, No. 926, OECD Publishing. 
France is one of the very few OECD countries where income inequality after taxes and transfers across households remained stable between 1985 and 2010. But behind this development lies a U-shaped evolution: after a drop until the mid-1990s, income inequality started to rise slowly during the 2000s. According to Cazenave et al. (2011), cuts in the personal income tax and the indexation of cash transfers to inflation (rather than to wage growth, for example) slightly reduced the progressivity of the tax and transfer system and were only partially offset by the introduction of the CSG (generalised social contribution) and the increase in the progressivity of the local residence tax (taxe d'habitation). As a result of booming asset prices, the income share of households in the top decile of the income distribution almost doubled from the mid-1990s to the late 2000 s.

Wealth inequality was twice as high as inequality of household disposable income in 2009 and increased between 2004 and 2010 (Chaput et al., 2011). The interaction between wealth concentration and capital incomes is likely to accentuate income inequality in the longer run. A large and increasing share of extremely high income earners, partly due to business income being taxed increasingly as personal income to avoid double taxation of corporate income, is the main reason for rising income inequality in the United States and other OECD countries (Figure 2). In France, however, the income share of the top 1\% and $0.1 \%$ of all earners is, respectively, only half and a third of that in the United States for instance, and these shares have risen only moderately since the mid-1990s.

In-kind benefits provided through government services reduce France's Gini coefficient, which measures income inequality, by about six percentage points, slightly less than the OECD average (OECD, 2011a) (Figure 3, Panel A). Health care and education services are the most effective in-kind benefits for lowering income inequality among French households (Figure 3, Panel B). The effectiveness of social housing, early childhood education and care (ECEC) and long-term care in decreasing income inequalities is, in contrast, rather limited.

Figure 2. The level and evolution of the share of top income earners in total income

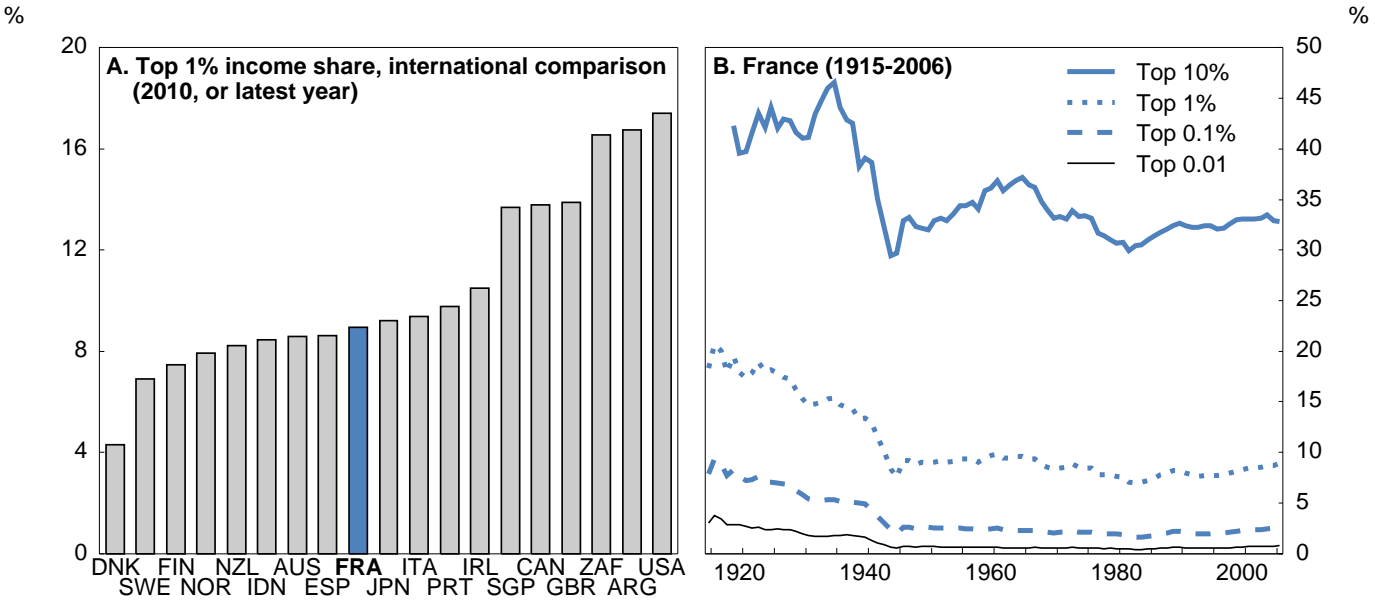

Source: The World Top Incomes Database, http://g-mond.parisschoolofeconomics.eu/topincomes. 
Figure 3. The impact of in-kind benefits on income inequality, late 2000s

Percentage point change in the Gini coefficient
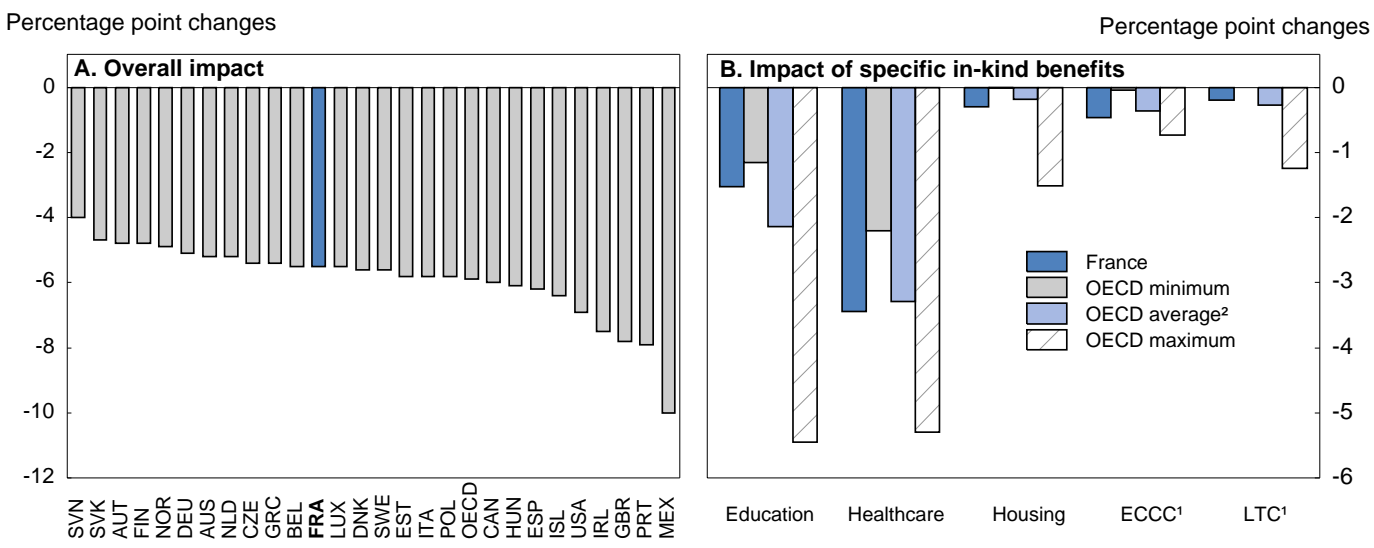

1. ECEC and LTC stand for early childhood care centre and long-term care, respectively.

2. Averages by category are computed across available data.

Source: OECD, Divided We Stand, 2011.

Much of the redistribution is achieved by the considerable volume of public spending, financed by a high level of taxes, which can weigh on economic performance. By tackling the sources and causes of household market income inequality, the government could more efficiently achieve the same level of inequality. It would be preferable to make changes to certain measures so as to reduce market income dispersion and thus the need for explicit redistribution and by better targeting. Then public spending and taxes could be diminished.

A recent OECD study identifies a number of policies that would help reduce income inequality in general (Koske et al., 2012). The ones that might be relevant for France are as follows: $i$ ) making access to education effectively equal and lessening the link from socio-economic background to educational outcomes; ii) elimination of labour-market dualism; iii) increased spending on active labour market policies; $i v$ ) better integration of immigrants (OECD, 2012a); and $v$ ) reduction of gender discrimination by increasing female labour market integration and lowering the gender wage gap. Also, continuing wage restraint at the minimum wage level would be beneficial because high minimum wages tend to increase rather than reduce income inequality and poverty by pricing low-skilled workers out of the labour market (Cahuc et al., 2008). The minimum wage in France (the SMIC) is very binding: it applies equally to all sectors and regions, and, even if only $10.6 \%$ of all employees are paid the SMIC, the wages of about $35 \%$ of workers depend directly or indirectly on its evolution.

\section{The French tax system is complex, changes frequently and induces serious distortions}

The French tax system is very complicated: there exist a large number of taxes and levies accompanied by a multitude of tax credits and exemptions. Tax provisions change frequently. This is burdensome, since, in order for a tax system not to penalise economic activity excessively, three guiding principles must be borne in mind: stability, neutrality and simplicity (Mirrlees Review, 2011). A neutral tax system does not interfere with household consumption decisions, nor influence the form of income received, the types of savings chosen, investment decisions nor whether current income is consumed now or in the future. The French tax system contains a large number of non-neutralities, which have important implications for employment, investment, saving and consumption decisions. Non-neutralities within asset classes arise mainly from numerous tax expenditures, which imply higher statutory rates and a very wide range of effective tax rates. Moving toward neutrality would also reduce complexity. Greater neutrality and 
simplicity would in turn reduce opportunities for tax evasion and avoidance and reduce administrative and compliance costs.

Stability is also desirable to minimise administrative and compliance costs and to reduce the negative effect of policy uncertainty on investment and saving decisions. Tax changes are reflected in asset prices and may create volatility and hence uncertainty regarding valuations. If changes are needed, they should be decided in a transparent framework and in line with a long-term strategy. However, non-neutrality is desirable in the presence of externalities, such as environmental pollution or positive spill-over effects from innovation. In addition to efficiency, redistribution is also central to any tax system. Nevertheless, there may be trade-offs between efficiency and redistribution: a more efficient system may do less to reduce income inequalities, and greater redistribution may harm incentives to work, save and invest.

\section{The taxation of labour is heavy despite substantial targeted measures}

Different parts of the working-age population are likely to respond differently to tax changes. Labour-supply responses for (unskilled) low-income workers, single parents, second earners (usually women) with dependent children and seniors are highly sensitive to the level of taxation. Studies show that low-skilled workers react at the extensive margin rather than at the intensive margin, i.e. they react more in terms of either taking a job or not than in terms of the number of hours worked (OECD, 2011b). Taxation can also alter geographic location choices for mobile workers, often highly skilled. French tax policies strengthen work incentives to low-income workers. Yet, while close to the European average, the employment rate of women with low educational attainment is fairly low in the absolute and in comparison with the best-performing countries (Figure 4).

A high tax wedge on earnings of low-income workers, in particular if coupled with a high minimum wage such as observed in France, curbs labour demand. Consecutive French governments have lowered employer social security contributions (SSCs) for very low-income earners since 1993. Since 2007, a relief of 26 percentage points ( 28.1 for firms with less than 20 employees) has been applied to those on minimum wages, with the relief linearly decreasing to zero for those earning 1.6 times the SMIC. Recent empirical evidence suggests that reduced SSCs may have created or maintained between 600000 and 1100000 jobs between 1998 and 2009, without causing low-income traps (Ourliac and Nouveau, 2012).

Nevertheless, as reduced social security contributions are phased out, the marginal (but also the average) tax wedge becomes very high, especially for the unmarried and single parents (Table 1), which may reduce the supply of labour of those at those wage levels. The government's competitiveness pact, which reduces the tax wedge by six percentage points up to 2.5 times the SMIC, is a welcome measure, even though the abrupt removal of the reduction would result in a wage trap around that threshold.

The overall tax burden comes not only from taxes and SSCs but also from the withdrawal of benefits upon entering the labour market (losing unemployment or social benefits) or working more hours (losing means-tested benefits). Benefit withdrawal can create sharp increases in marginal effective tax rates (METRs). However, there is a trade-off: a more gradual cut-off of benefits could reduce such threshold effects, but doing so is more costly. That cost could be financed either by higher taxes, which may reduce the labour supply of other workers, or via lower benefits, which would hurt the poor (OECD, 2011b). 
Figure 4. Employment rates, 2010

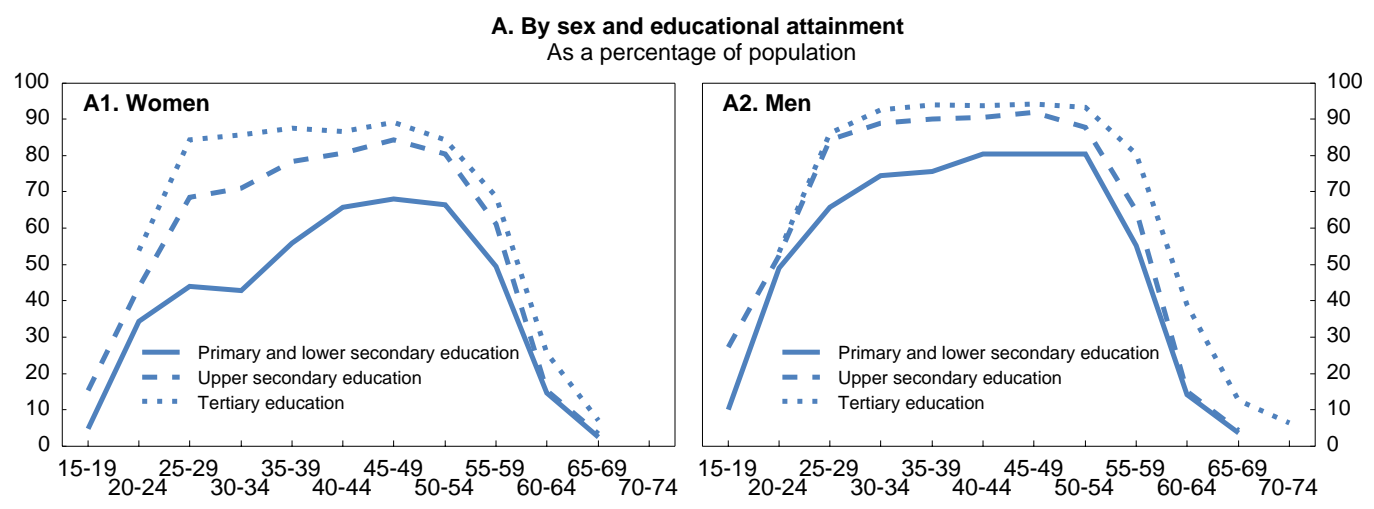

B. Female employment rates in France compared to other European countries, by educational attainment As a percentage of population
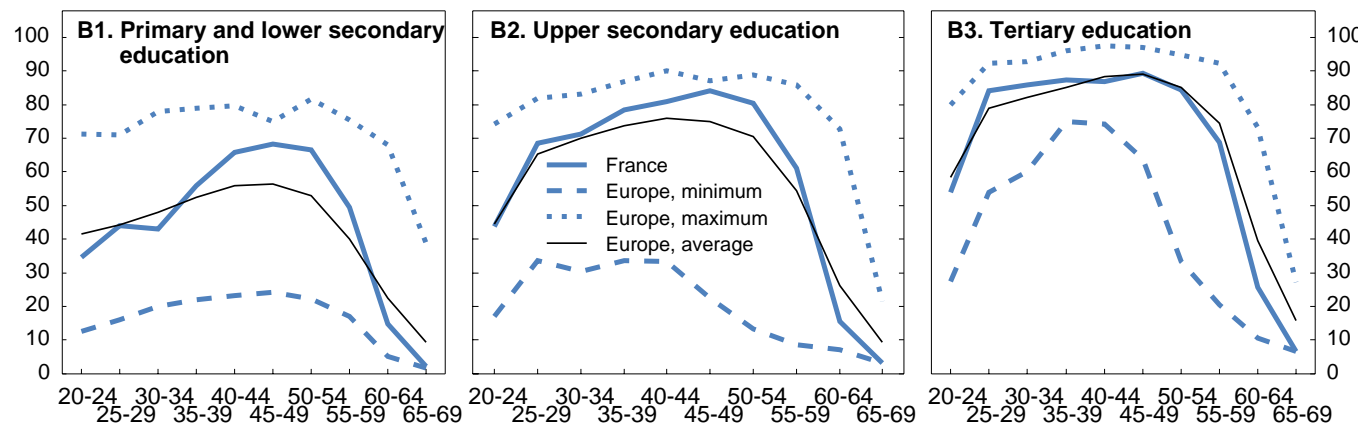

C. Ratio female-to-male employment rate in France compared to other European countries, by educational attainment
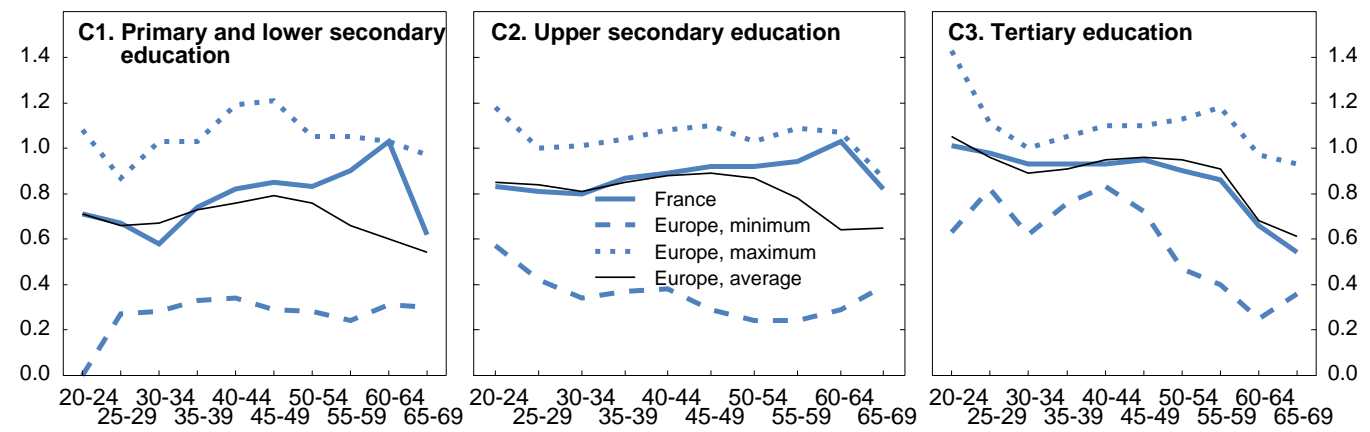

Source: Eurostat.

The OECD's Tax-Benefit models show that French METRs never exceed 100\% (Table 2). However, groups that are more sensitive to marginal rates (low-wage workers and single parents) do not face lower METRs than others. For the transition from unemployment benefits to full-time work, the METR is about $80 \%$, independent of family composition. Such a high rate is problematic, given the combination of long unemployment benefit duration (two to three years) without degressivity and poor activation policies. Unemployment benefit withdrawal accounts for two-thirds and income taxes and employees' SSCs for one third of the high marginal rate. In-work tax credits play only a minor role in offsetting these factors. METRs are somewhat lower for moving from social assistance to a job. At the intensive margin, the METR is particularly high for moving from one-third time to full-time work for single-earner families with two children. 
ECO/WKP(2013)30

Table 1. Tax wedge in \% of labour costs for different wage levels and household types, 2011

\begin{tabular}{|c|c|c|c|c|c|c|c|c|c|c|c|}
\hline \multicolumn{6}{|c|}{ Single } & \multicolumn{6}{|c|}{ Married couple } \\
\hline \multicolumn{3}{|c|}{ No children } & \multicolumn{3}{|c|}{ Two children } & \multicolumn{3}{|c|}{ No children } & \multicolumn{3}{|c|}{ Two children } \\
\hline \multicolumn{6}{|c|}{$67 \%$ of average wage } & \multicolumn{6}{|c|}{$100 \%+33 \%$ of average wage } \\
\hline & MARG & AVE & & MARG & AVE & & MARG & AVE & & MARG & AVE \\
\hline Belgium & 66.3 & 49.7 & United Kingdom & 76.3 & 7.1 & Belgium & 66.3 & 48 & Belgium & 66.3 & 41.4 \\
\hline France & 63.2 & 46.5 & Ireland & 67.9 & -24.6 & Hungary & 63.5 & 46.7 & Hungary & 63.5 & 34.3 \\
\hline Austria & 56.9 & 43.7 & Belgium & 66.3 & 35.5 & Austria & 60.6 & 44.7 & Austria & 60.6 & 37.2 \\
\hline Germany & 56.0 & 45.6 & Canada & 60.5 & -6.3 & Finland & 57.2 & 39.3 & Israel & 60.3 & 12.2 \\
\hline Italy & 54.0 & 44.5 & Australia & 58.0 & -6.0 & Germany & 56.0 & 45.6 & Finland & 57.2 & 35.5 \\
\hline Finland & 53.1 & 37.2 & France & 57.7 & 38.4 & Italy & 54.1 & 44.5 & Germany & 55.7 & 38.9 \\
\hline Hungary & 51.6 & 45.2 & Austria & 56.9 & 26.8 & France & 51.3 & 45.6 & Italy & 55.1 & 40.3 \\
\hline Portugal & 50.7 & 33.1 & Czech Republic & 55.7 & 16.4 & Norway & 51.2 & 35.0 & Czech Republic & 54.0 & 30.7 \\
\hline Netherlands & 48.7 & 33.1 & Italy & 54.5 & 29 & Slovenia & 51.0 & 40.2 & Norway & 51.2 & 31.9 \\
\hline Czech Rep. & 48.6 & 39.5 & Germany & 54.2 & 31.2 & Portugal & 50.7 & 34.0 & Portugal & 50.7 & 30.4 \\
\hline Sweden & 45.6 & 40.7 & Finland & 53.1 & 26.4 & Czech Republic & 48.6 & 40.3 & New Zealand & 50.0 & 7.0 \\
\hline Spain & 45.2 & 36.6 & Spain & 52.4 & 29.5 & Spain & 48.1 & 36.9 & Spain & 48.1 & 35.8 \\
\hline Slovak Republic & 44.4 & 36.1 & Netherlands & 51.7 & 11.5 & Sweden & 47.9 & 41.0 & Sweden & 47.9 & 36.9 \\
\hline Slovenia & 43.6 & 38.6 & United States & 51.4 & 8.2 & Netherlands & 47.0 & 33.8 & Iceland & 47.9 & 27.6 \\
\hline Iceland & 43.5 & 29.2 & Portugal & 50.7 & 23.7 & Slovak Republic & 44.4 & 35.8 & Netherlands & 47.0 & 29.2 \\
\hline Norway & 43.2 & 34.2 & Iceland & 50.6 & 18.5 & Iceland & 43.5 & 29.5 & France & 46.9 & 40.0 \\
\hline Estonia & 42.9 & 38.8 & Sweden & 45.6 & 32.5 & OECD & 42.9 & 32.2 & Canada & 44.5 & 23.8 \\
\hline Luxembourg & 42.5 & 29.2 & Slovak Republic & 44.4 & 23.6 & Estonia & 42.9 & 38.8 & Slovak Republic & 44.4 & 29.5 \\
\hline Turkey & 42.2 & 35.4 & OECD & 43.8 & 15.6 & Denmark & 42.3 & 37.0 & OECD & 44.1 & 27.2 \\
\hline Denmark & 40.9 & 36.8 & Norway & 43.2 & 21.4 & Turkey & 42.2 & 37.9 & Slovenia & 43.6 & 30.6 \\
\hline OECD & 40.9 & 31.6 & Estonia & 42.9 & 24.3 & Luxembourg & 40.9 & 27.7 & Estonia & 42.9 & 34.2 \\
\hline United Kingdom & 40.2 & 28.5 & Luxembourg & 42.5 & 2.4 & Canada & 40.8 & 27.7 & Denmark & 42.3 & 32.1 \\
\hline Australia & 39.1 & 20.6 & Turkey & 42.2 & 34.2 & United Kingdom & 40.2 & 28.5 & Turkey & 42.2 & 37.3 \\
\hline Ireland & 37.7 & 21.3 & Denmark & 40.9 & 11.4 & Israel & 38.6 & 16.6 & Luxembourg & 40.9 & 17.7 \\
\hline Poland & 36.1 & 33.4 & Hungary & 35.8 & 20 & Ireland & 37.7 & 20.3 & United Kingdom & 40.2 & 25.0 \\
\hline Canada & 33.5 & 26.1 & Slovenia & 32.9 & 12.7 & Poland & 36.1 & 33.4 & Ireland & 37.7 & 13.3 \\
\hline United States & 32.5 & 27.2 & Japan & 31.6 & 19.7 & Japan & 35.8 & 30.0 & Poland & 36.1 & 29.6 \\
\hline Japan & 31.6 & 29.5 & Poland & 28.4 & 28.4 & Australia & 35.4 & 22.9 & Japan & 35.8 & 25.1 \\
\hline Israel & 30.0 & 13.0 & Switzerland & 18.7 & 2.8 & United States & 32.5 & 27.8 & Australia & 35.4 & 17.9 \\
\hline Switzerland & 23.0 & 18.0 & Korea & 18.6 & 17.0 & New Zealand & 30.0 & 14.8 & United States & 32.5 & 22.7 \\
\hline Korea & 19.8 & 17.7 & New Zealand & 17.5 & -18.7 & Korea & 28.8 & 19.4 & Korea & 25.1 & 17.9 \\
\hline New Zealand & 17.5 & 12.9 & Mexico & 17.5 & 13.2 & Switzerland & 26.0 & 18.6 & Switzerland & 23.6 & 11.1 \\
\hline Mexico & 17.5 & 13.2 & Israel & 16.8 & 0.1 & Mexico & 18.7 & 14.4 & Mexico & 18.7 & 14.4 \\
\hline Chile & 7.0 & 7.0 & Chile & 7.0 & 6.0 & Chile & 7.0 & 7.0 & Chile & 7.0 & 4.9 \\
\hline
\end{tabular}

Note: MARG and AVE denote the marginal and average tax wedge, respectively.

Source: OECD, Taxing Wages, http://www.oecd.org/tax/taxpolicyanalysis/taxingwages.htm

Two important instruments are in place to reduce the impact of benefit withdrawals on the implicit marginal tax rate of low-income households. The first is a refundable, in-work tax credit (prime pour l'emploi, PPE), a tax credit for low-income workers created in 2001. The second is embedded in a more general programme targeted at poverty reduction, the active solidarity income (revenu de solidarité active, RSA). RSA has a component, the activity RSA, which provides a bonus to those who have modest revenue from labour earnings. The PPE and activity RSA are complementary: activity RSA tops up basic social transfers and earnings to enhance incentives to work, to which PPE is added at higher but still modest levels of income (Figure 5). 
Table 2. Marginal effective tax rates (\%), 2010

\begin{tabular}{|c|c|c|c|c|}
\hline & \multirow{3}{*}{ Family situation } & \multicolumn{2}{|c|}{ Extensive margin } & \multirow{2}{*}{$\begin{array}{c}\text { Intensive margin } \\
\begin{array}{c}\text { From part-time } \\
\text { to full-time }\end{array}\end{array}$} \\
\hline & & $\begin{array}{l}\text { From unemployment } \\
\text { benefit to full-time job }\end{array}$ & $\begin{array}{l}\text { From social assistance } \\
\text { to full-time job }\end{array}$ & \\
\hline & & \multicolumn{2}{|c|}{$33 \%$ of average wage level } & $50 \%=>100 \%$ \\
\hline \multirow[t]{3}{*}{ No children } & Single person & 87 & 67 & 36 \\
\hline & One-earner married couple & 86 & 62 & 44 \\
\hline & Two-earner married couple & 88 & 15 & 35 \\
\hline \multirow[t]{4}{*}{ Two children } & Lone parent & 86 & 55 & 47 \\
\hline & One-earner married couple & 85 & 56 & 55 \\
\hline & Two-earner married couple & 87 & 31 & 34 \\
\hline & & \multicolumn{2}{|c|}{$67 \%$ of average wage level } & $33 \%=>100 \%$ \\
\hline \multirow[t]{3}{*}{ No children } & Single person & 77 & 55 & 50 \\
\hline & One-earner married couple & 72 & 57 & 60 \\
\hline & Two-earner married couple & 76 & 27 & 38 \\
\hline \multirow[t]{4}{*}{ Two children } & Lone parent & 72 & 61 & 75 \\
\hline & One-earner married couple & 72 & 61 & 75 \\
\hline & Two-earner married couple & 75 & 33 & 30 \\
\hline & & \multicolumn{2}{|c|}{$100 \%$ of average wage level } & $67 \%=>100 \%$ \\
\hline \multirow{3}{*}{ No children } & Single person & 76 & 48 & 32 \\
\hline & One-earner married couple & 75 & 50 & 39 \\
\hline & Two-earner married couple & 76 & 28 & 32 \\
\hline \multirow[t]{3}{*}{ Two children } & Lone parent & 73 & 55 & 37 \\
\hline & One-earner married couple & 73 & 57 & 50 \\
\hline & Two-earner married couple & 75 & 32 & 31 \\
\hline
\end{tabular}

Source: OECD Tax-Benefit models, http://www.oecd.org/els/benefitsandwagesstatistics.htm

Figure 5. Simplified depiction of the RSA

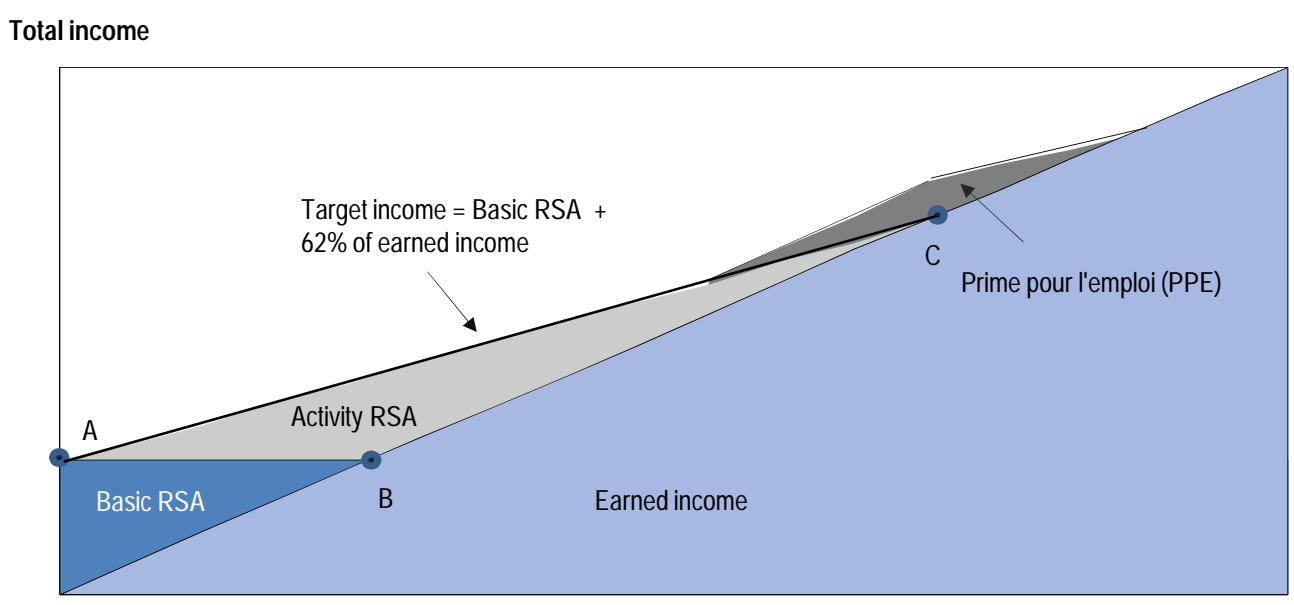

Earned income

Source: Bourgeois and Tavan (2009).

But activity RSA and PPE are not fully consistent with each other. RSA is paid on a monthly basis based on the previous quarter's earnings, while PPE is deducted from taxes paid a year after labour income is earned. Whether someone is eligible for activity RSA depends on household revenue. By contrast, the basis for means-testing PPE is individual income (Bonnefoy et al., 2009), with a ceiling on total household income. A recent evaluation of activity RSA shows that almost $70 \%$ of individuals who would be eligible for activity RSA do not claim it. A major reason for this is lack of information regarding RSA eligibility 
(Bourguignon, 2011). Against this backdrop, the government should streamline and simplify the current system by merging activity RSA and PPE and by paying the income support on a monthly basis using immediately previous earnings to maximise the incentive effects on labour supply. The government announced in its multi-year plan against poverty (see Box 3 of the Assessment and Recommendations section) a better harmonisation between the RSA and the PPE.

\section{Joint family income taxation may discourage female labour force participation}

Joint family taxation is compulsory in France: the tax burden depends on income declared in the joint tax declaration, divided by the part, which is two for a childless couple. The main argument for family taxation is that of horizontal equity: equal tax rates for equal pre-tax standards of living ("à niveau de vie égal, taux d'imposition égal"). The presence of a second adult does not double living costs, however, because of scale effects, and therefore a weight of two favours couples. Furthermore, family taxation favours couples with very different earnings relative to individual taxation. French income taxation also accounts for the number of children, as discussed below.

A major drawback of the joint taxation of spouses or partners is that it can create work disincentives for second earners, usually women, especially if the first earner falls in a higher tax bracket and that the number of part is too high: a second earner entering the labour force is taxed at a higher marginal rate than a single individual would be. For this reason, many OECD countries have opted for individual taxation (OECD, 2011d). In France, the average tax wedge, computed based on the gross wage minus employee SSCs and personal income tax (including CSG), is about 5 percentage points higher for a second earner without children than for a single earner. The gap widens to 10 percentage points in the presence of two children (OECD, 2011d). The effective marginal and average tax rates on second earners are likely to be considerably higher if cash transfers and in-kind benefits received on a family basis are also taken into accounted. Carbonnier (2007)'s findings would suggest that even if the overall impact on the female participation rate is limited, for certain categories of women - including those who are childless, have children older than three years or whose spouses earn between 2.5 and 4 times the SMIC - it reacts more strongly to incentives. On a sample of OECD countries, Jaumotte (2003) shows that joint taxation reduces the participation rate of women significantly. The government should encourage female labour force participation by moving to individual-based personal income taxation.

\section{Incentives for older workers to keep working can be further improved}

There is an asymmetry in the treatment of earnings and pensions with regard to SSCs, which may provide disincentives to work longer. Pension income enjoys reduced rates for the CSG $(6.6 \%$ instead of $7.5 \%$ for employees) or even zero rates below a certain threshold, costing the budget about $0.35 \%$ of GDP (Cour des Comptes, 2012). In addition, pensioners are not subject to SSCs relating to health care. Eliminating this asymmetric treatment would help reduce, in a budget-neutral way, the tax wedge on labour income. At the same time, workers above the statutory retirement age, in particular if they receive pensions simultaneously, should pay only SSCs applying to current pensioners, such as for health care.

Pensioners also receive favourable tax treatment (compared to the active population) on local taxes: below a certain income threshold they are entitled to full or partial exoneration from recurrent property taxes (taxe d'habitation and taxe foncière) and capital gains tax on property sales. Such tax breaks overlap with (though the income brackets are slightly different) and complement the main instrument to counter old-age poverty: the minimum pension (allocation de solidarité aux personnes âgées). While the 10\% reduction of the personal income tax base (which is capped) to which every wage earner is entitled is viewed as a lump-sum proxy for work-related costs, the similar reduction from pension income, even with a much lower upper ceiling for the absolute deduction, is more difficult to justify. In addition, pensioners can take advantage of a flat amount tax reduction below a certain income threshold (about 23000 euros in 
2012), and pensioners who had three children do not have to pay tax on the $10 \%$ pension premium for children. These tax reductions and exemptions are strongly regressive and amount to about $0.3 \%$ of GDP (Cour des Comptes, 2012). The government should simplify the current system of minimum pensions, eliminate pensioners' tax breaks, discontinue the $10 \%$ tax reduction for pension income and, if needed, increase the minimum pension (which, however, was almost twice the amount of social assistance (basic RSA) for a single person in 2012).

The so-called surcote (bonus) ensures an increase of 5\% in annual pension benefits, a figure close to actuarial neutrality, by working an extra year beyond the period required for a full pension. But a number of useful measures encourage older people to work longer. People at pension age are allowed to work while receiving pensions (cumul employ-retraite), and it is also possible to retire only partially while continuing to work part-time (retraite progressive). Finally, employers cannot lay off individuals wishing to work until the age of 69. But unemployed people over 50 can receive unemployment benefits for up to three years rather than the standard two years (which may be extended substantially by long-term unemployment benefits (allocation de solidarité spécifique, ASS and allocation équivalent retraite, AER)). This constitutes an implicit early retirement scheme and as such should be abolished as discussed below in more detail. In June 2012, the government decided to lower the minimum retirement age to 60 for persons who by that age had contributed the length of time required for a full pension. The absence of a bonus for quarterly contributions beyond the contribution period required for a full pension and prior to the legal minimum age (62) discourages those eligible for early retirement on long-career grounds from continuing to work. It would therefore be advisable to change the rules for the bonus so that quarterly contributions beyond the legal duration required for a full-rate pension would increase the amount of the pension.

\section{The mobility of high-income earners will limit the revenue yield of raising the top marginal tax rate}

In theory, top incomes may react to higher marginal rates through three channels: $i$ ) reduced labour supply, ii) tax avoidance through income shifting due to tax loopholes that narrow the tax base, and iii) the power of top executives to influence firms' compensation committees. Prerequisites to increase top rates with no loss in tax revenues are in fact a broad tax base with few loopholes and little opportunity for tax arbitrage. The government capped tax expenditures on personal income tax at 10000 euros per taxpayer, though some tax expenditures are not concerned by this limit, which is an attempt to close the tax-arbitrage channel. The only unavoidable factor that limits the size of the revenue-maximising top marginal rate is the labour-supply elasticity. Piketty et al. (2011) show for a panel of 18 OECD countries that the labour supply of high income earners has a low elasticity. In the case of the United States, Saez et al. (2012) show that once the possibilities for tax arbitrage have been eliminated, the labour supply of high income earners is affected little by tax increases. According to these studies, top marginal tax rates higher than those observed in many countries may be optimal. However, they do not factor in the possibility of migration to countries with lower top marginal tax rates. In fact, while there is little direct empirical evidence on the migration of top income earners as a function of changes in taxation, empirical evidence on the international migration of football superstars in Europe shows that migration decisions depend to a large extent on changes in top income tax rates (Kleven et al., 2010).

The government has added a new bracket of $45 \%$ (in addition to the existing $41 \%$ bracket) for earnings exceeding 150000 euros per individual share of household income (part fiscale). The Mirrlees Review (2011) suggested that the revenue-maximising top marginal rate, including SSCs, should be around 50 to $60 \%$. Employers' and employees' SSCs combined with the proposed top rate of $45 \%$ imply a marginal rate of about 62 to $65 \%$. For individual income in excess of 1 million euros, a temporary bracket of $75 \%$ (including the CSG of 8\%) was legislated for 2012 and 2013, generating predicted tax revenues of $0.02 \%$ of GDP. Such hikes are meant to increase tax progressivity, and the marginal rate of $75 \%$ was presented as a political symbol of fiscal justice. But the Constitutional Court invalidated the $75 \%$ bracket 
because it applied to individuals' revenues and not to family income, violating the principle of equal sharing of the tax burden because households with the same revenue may be taxed differently depending on the composition of individual labour and capital income. Increasing tax rates to $75 \%$ would be counterproductive if it results in lower revenues. The top marginal rate of $75 \%$ would result in an effective top marginal rate of 79\%. On the one hand, the work of Piketty et al. (2011) and Saez et al. (2012) suggests that the optimal top marginal rates could be higher than the current rates. On the other hand, according to Simula and Trannoy (2009), in a model calibrated to French data, the previous $40 \%$ top rate might already have been too high to prevent emigration and tax-base erosion. These authors even argue that revenue-maximising top marginal rates could be below the rates applied at lower income levels, for which the propensity to emigrate is low. Generally speaking, a tax base narrowed by numerous tax expenditures, coupled with high marginal tax rates is not best practice: rather a broad tax base and lower marginal tax rates are preferred.

\section{The taxation of capital}

\section{Effective marginal tax rates on capital income vary substantially}

Taxes applied to capital income of individuals and corporations are one type of capital taxation. While certain economic modelling setups would predict that capital income should not be taxed at all (Atkinson and Stiglitz, 1976), taxing capital at non-zero rates can be desirable for a number of reasons. First, the most highly productive individuals have a higher capacity to pay taxes: they tend to save more and to obtain higher yields on their savings. Second, capital income taxes can be viewed as a tax on bequests spread over someone's lifetime. Third, taxing capital income can encourage individuals to invest in human rather than financial capital. Lastly, constituting precautionary savings in order to protect oneself against permanent negative shocks can create disincentives to work if these shocks do not materialise (Denk, 2012). An important practical concern is to avoid tax arbitrage from labour to capital income for small businesses and the self-employed. At the same time, high taxes on capital income often imply double taxation of labour income, given that the primary source of savings is labour earnings. High taxes could also encourage taxpayers to move capital out of the country in a context of high capital mobility (Denk, 2012).

The government's recent decision to phase out the dual income tax system through integrating capital income into the personal income tax schedule may increase considerably the tax burden for those falling into the upper tax brackets (top marginal rate of $45 \%$ and social levies of $15.5 \%$ ) compared to the previous, already high flat tax rate of close to $40 \%$ (21\% for dividends and $24 \%$ for interest income plus social levies of $15.5 \%$ ). Capital gains (excluding one's primary residence) are also henceforth integrated into the PIT schedule. Dividends are subject to multiple taxation: corporate tax, the 3\% dividends tax (at the corporate level) adopted in July 2012, income tax (though with a 40\% exclusion, which limits double taxation) and social levies. This implies a much higher effective tax rate on dividends than before and compared to that on interest-bearing assets. Double taxation of dividends is avoided or to a large extent attenuated in Canada, Chile, Mexico and New Zealand (Ernst \&Young, 2011) by accounting for corporate income taxes in calculating personal taxes due on dividends. The French government should reduce the extent of multiple taxation of dividends.

At the same time, a number of savings vehicles benefit from preferential tax conditions, even though some of these tax expenditures were scaled back in 2012. Gains stemming from share savings plans (plan d'épargne en actions, PEA) are exempt from income tax (but not from CSG) if assets are withdrawn after five years. Workers' voluntary savings plans at the company level (plan d'épargne salariale) also enjoy tax breaks and are subject to reduced SSCs. Income from savings in the form of life insurance is taxed only when capital is withdrawn and at lower rates after eight years of possession. Finally, a number of savings deposits (livret A, livret d'épargne-populaire, livret d'épargne-logement, plan d'épargne-logement, livret jeune, livret d'épargne-entreprise, livret de développement durable) are exempt from tax and in some cases 
not subject to social levies. The recent increase in the ceilings of livret $A$ and livret de développement durable accentuates the existing distortions. There is therefore a general need for reforming the taxation of savings by applying similar tax treatment to all products.

The absence of neutrality for investment in housing is also an important issue: taxing income from renting real estate but not imputed rents encourages home ownership, as the previous Survey argued (OECD, 2011e). The standard deviation of effective tax rates (and thus the divergence from neutrality across asset classes - interest, dividends, rental and owner-occupied housing) was already large prior to the integration of capital revenues and gains into the PIT schedule in 2013 (Figure 6, Panel A). A related issue is the treatment of capital gains, which should be subject to the same tax across different assets, and all gains should be deemed to have been realised at death.

Figure 6. The dispersion of top marginal effective tax rates across different asset classes, $2011^{1}$
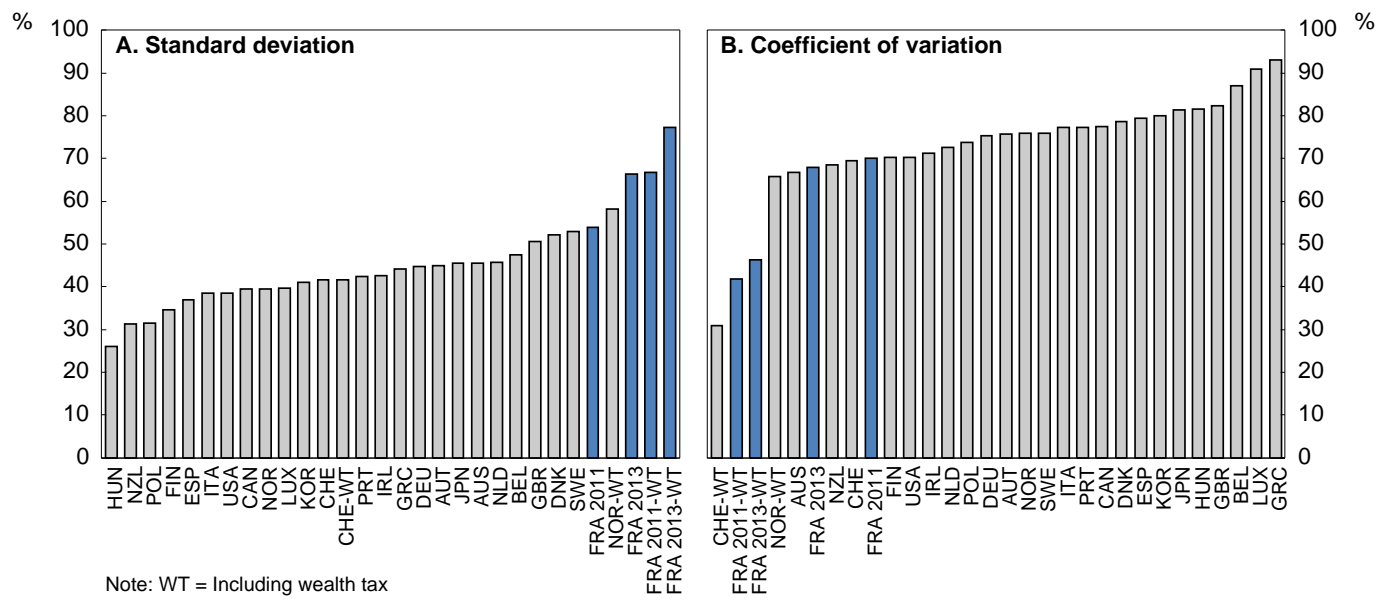

1. Underlying the calculations are the top marginal effective tax rates of the four asset classes presented in Table 3 based on a nominal return of $4 \%$ and an inflation rate of $2 \%$.

Source: OECD calculations based on Table 3, displayed below.

Inflation affects the effective tax rate on capital income, if the tax base is nominal income. A high statutory tax rate on the nominal return may imply a very high effective tax rate on the real return, especially if inflation is high and/or the real return is low. In an extreme case, taxing the nominal rate could even lower the real value of the capital stock. These effects would be eliminated by basing taxation of capital income and gains on real, not nominal returns, notwithstanding the technical problems this might pose. To date, most countries, including France, tax the nominal rather than real return on capital. However, in Israel and Luxembourg, capital gains taxes are levied on the increase in the inflation-adjusted value of secondary residences, while a special construction-sector price index is applied in Portugal to calculate real capital gains. Capital gains, a form of capital income, should be taxed similarly to other capital income.

As a result of taxing nominal rather than real returns, METRs, calculated assuming a nominal return of $4 \%$ and an inflation rate of $2 \%$, can be very high, even above $100 \%$, implying a depreciation of the real stock of capital. Table 3 shows that, for assets not benefiting from the numerous tax breaks discussed earlier, France is among the countries with the highest METRS: about $80 \%$ for income from interest-bearing assets and above $100 \%$ for dividends and rental income. METRs are generally zero on owner-occupied housing. 
ECO/WKP(2013)30

Table 3. Effective top marginal tax rates on real returns of different asset classes, 2011

Per cent

\begin{tabular}{|c|c|c|c|c|c|c|c|c|}
\hline & \multicolumn{4}{|c|}{ Nominal return=4\%, inflation=2\% } & \multicolumn{4}{|c|}{ Nominal return=8\%, inflation $=2 \%$} \\
\hline & $\begin{array}{l}\text { Interest } \\
\text { income }\end{array}$ & Dividends & $\begin{array}{l}\text { Owner } \\
\text { occupied }\end{array}$ & Rental & $\begin{array}{l}\text { Interest } \\
\text { income }\end{array}$ & Dividends & $\begin{array}{l}\text { Owner } \\
\text { occupied }\end{array}$ & Rental \\
\hline Austria & $50 \%$ & $88 \%$ & $0 \%$ & $100 \%$ & $33 \%$ & $58 \%$ & $0 \%$ & $67 \%$ \\
\hline Belgium & $30 \%$ & $88 \%$ & $0 \%$ & $100 \%$ & $20 \%$ & $59 \%$ & $0 \%$ & $67 \%$ \\
\hline Czech Republic & $30 \%$ & $62 \%$ & $0 \%$ & $30 \%$ & $20 \%$ & $42 \%$ & $0 \%$ & $20 \%$ \\
\hline Denmark & $50 \%$ & $113 \%$ & $0 \%$ & $103 \%$ & $33 \%$ & $75 \%$ & $0 \%$ & $69 \%$ \\
\hline Estonia & $42 \%$ & $42 \%$ & $0 \%$ & $42 \%$ & $28 \%$ & $28 \%$ & $0 \%$ & $28 \%$ \\
\hline Finland & $56 \%$ & $81 \%$ & $0 \%$ & $60 \%$ & $37 \%$ & $54 \%$ & $0 \%$ & $40 \%$ \\
\hline France 2011 & $79 \%$ & $115 \%$ & $0 \%$ & $113 \%$ & $53 \%$ & $77 \%$ & $0 \%$ & $75 \%$ \\
\hline with wealth tax & $169 \%$ & $205 \%$ & $63 \%$ & $203 \%$ & $83 \%$ & $107 \%$ & $21 \%$ & $105 \%$ \\
\hline Hungary & $32 \%$ & $64 \%$ & $0 \%$ & $32 \%$ & $21 \%$ & $43 \%$ & $0 \%$ & $21 \%$ \\
\hline Iceland & $20 \%$ & $72 \%$ & $0 \%$ & $64 \%$ & $13 \%$ & $48 \%$ & $0 \%$ & $42 \%$ \\
\hline with wealth tax & $95 \%$ & $147 \%$ & $75 \%$ & $139 \%$ & $38 \%$ & $73 \%$ & $25 \%$ & $67 \%$ \\
\hline Ireland & $60 \%$ & $97 \%$ & $0 \%$ & $82 \%$ & $40 \%$ & $64 \%$ & $0 \%$ & $55 \%$ \\
\hline Israel & $50 \%$ & $78 \%$ & $0 \%$ & $90 \%$ & $33 \%$ & $52 \%$ & $0 \%$ & $60 \%$ \\
\hline Italy & $40 \%$ & $73 \%$ & $0 \%$ & $86 \%$ & $27 \%$ & $49 \%$ & $0 \%$ & $57 \%$ \\
\hline Japan & $40 \%$ & $103 \%$ & $0 \%$ & $80 \%$ & $27 \%$ & $69 \%$ & $0 \%$ & $53 \%$ \\
\hline Korea & $40 \%$ & $96 \%$ & $0 \%$ & $70 \%$ & $27 \%$ & $64 \%$ & $0 \%$ & $47 \%$ \\
\hline Luxembourg & $20 \%$ & $79 \%$ & $0 \%$ & $76 \%$ & $13 \%$ & $52 \%$ & $0 \%$ & $51 \%$ \\
\hline Mexico & $40 \%$ & $60 \%$ & $0 \%$ & $35 \%$ & $27 \%$ & $40 \%$ & $0 \%$ & $23 \%$ \\
\hline Netherlands & $60 \%$ & $88 \%$ & $0 \%$ & $104 \%$ & $40 \%$ & $58 \%$ & $0 \%$ & $69 \%$ \\
\hline Sweden & $60 \%$ & $97 \%$ & $0 \%$ & $122 \%$ & $40 \%$ & $65 \%$ & $0 \%$ & $81 \%$ \\
\hline Switzerland & $70 \%$ & $74 \%$ & $0 \%$ & $96 \%$ & $47 \%$ & $49 \%$ & $0 \%$ & $64 \%$ \\
\hline with wealth tax & $145 \%$ & $149 \%$ & $75 \%$ & $171 \%$ & $72 \%$ & $74 \%$ & $25 \%$ & $89 \%$ \\
\hline Turkey & $30 \%$ & $64 \%$ & $0 \%$ & $40 \%$ & $20 \%$ & $43 \%$ & $0 \%$ & $27 \%$ \\
\hline United Kingdom & $40 \%$ & $105 \%$ & $0 \%$ & $100 \%$ & $27 \%$ & $70 \%$ & $0 \%$ & $67 \%$ \\
\hline United States & $60 \%$ & $90 \%$ & $0 \%$ & $70 \%$ & $40 \%$ & $60 \%$ & $0 \%$ & $47 \%$ \\
\hline
\end{tabular}

Note: Returns are assumed to be realised through capital income and not through capital gains and that the top marginal rate of the income tax schedule is applied unless there is a withholding tax or if no taxes apply at the personal level. Tax breaks on various asset types are not taken into account. The effective tax rate on dividends includes corporate and personal income taxes and social security contributions. For owner-occupied housing, local property taxes are not included. France's effective tax rate on owner-occupied housing accounts for the fact that only $70 \%$ of the value of the property enters the tax base. The PIT marginal rates of $41 \%$ (2011) and 45\% (2013) are used for France.

Source: OECD calculations.

The prevailing statutory rate of the corporate income tax of $34.4 \%$ (base rate of $33.33 \%$, multiplied by 1.0333 to account for social contributions) is among the highest in the OECD, even though it was cut by around five percentage points over the last two decades. Only Japan and the United States have higher statutory corporate income tax rates (Figure 7). The rate rises to $36.1 \%$ if one adds the exceptional $5 \%$ tax for big companies with an annual turnover in excess of 250 million euros for 2012 and 2013. For an open economy with free capital movements, the level of corporate income taxes is an important factor determining a country's attractiveness for foreign investors and its international competitiveness. 
Figure 7. Corporate income tax (CIT) rates and revenue from those taxes as a $\%$ of total tax revenue

$\%$

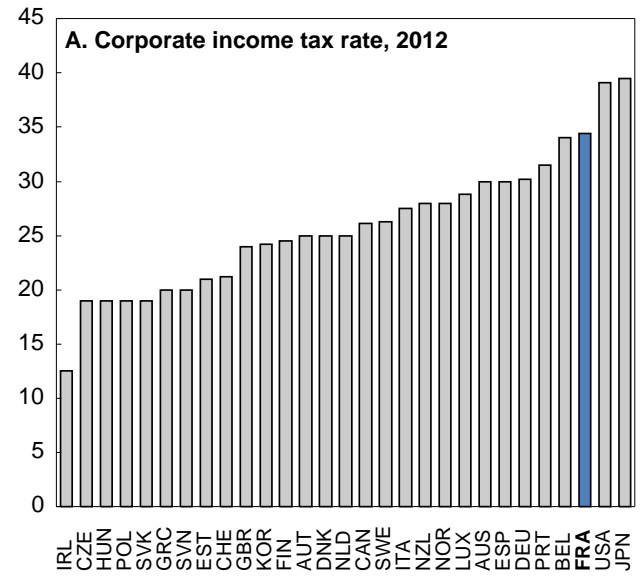

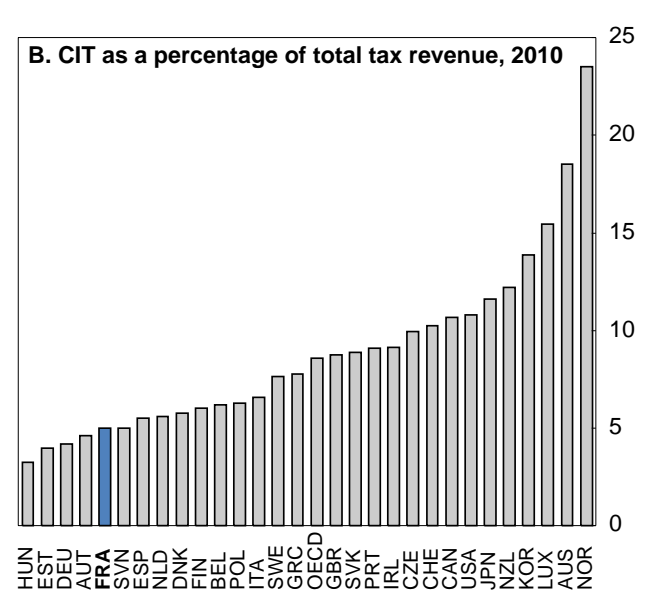

$\%$

Source: OECD, Revenue Statistics 2013; Ernst \& Young (2011).

To avoid this problem, the nominal corporate income tax rate should be reduced in a revenue-neutral way by continuing to broaden the tax base. France's high statutory tax rate is coupled with low revenues, measured either as a share of GDP or total tax revenues (Figure 7) because of the large number of loopholes and tax breaks. As the Conseil des Prélèvements Obligatoires (2009) points out, the result is an effective tax rate paid on realised profits of only $8 \%$ for companies included in the CAC40 and $22 \%$ for SMEs. More generally, the report finds that the effective tax rate diminishes as company size increases. The three major tax expenditures include: $i$ ) the tax consolidation regime, whereby the profits and losses of individual companies belonging to the same group may be consolidated (CPO, 2010), ii) the deductibility of interest payments on debt financing, and iii) the tax credit on investment in research and development. The way global corporations consolidate their profits depends on tax rates in other countries, so having a high nominal tax rate naturally encourages businesses to pay taxes elsewhere. If interest income is taxed at the household level, interest deductibility can be justified to avoid double taxation. The government's decision to cap the deductibility of interest payments on borrowing goes in the direction of double taxation but at the same time will reduce the differential cost of debt and equity financing.

While the tax burden falls with company size, there is a special corporate tax rate of $15 \%$ applying to profits not exceeding 38000 euros for small businesses owned by physical persons and with annual turnover not exceeding 8 million euros. The experience of many OECD countries shows that a tax rate on small businesses much below that for self-employed individuals and wage earners will encourage income shifting from labour to capital income. This is not a danger in France because the average tax rate on net wages of 38000 euros is exactly $15 \%$.

\section{Taxation of the net capital stock}

Only a few OECD countries, including France, have net wealth taxes (Table 4). In principle, such taxes can be viewed as taxes on capital income. For instance, a $1 \%$ tax on the asset stock would correspond to a tax rate of $25 \%$ on the nominal return and $50 \%$ on the real return, under the assumption of a nominal return of $4 \%$ and an inflation rate of $2 \%$. In France, wealth tax is levied on top of the direct taxation of capital income and yields receipts of $0.3 \%$ of GDP), and, as a result, substantially increases the tax rate on capital. Table 3 above shows that net wealth taxes almost double the maximum effective tax rate on capital income in all four OECD countries having such a tax. For those taxed at the marginal rate of $45 \%(41 \%$ in 2011), the top marginal wealth tax rate in France generates effective tax rates of close to $200 \%$ for interest income, dividends and income from rented dwellings. This implies that the real value of the capital stock 
of the wealthiest French citizens decreases significantly. Too high METRs could prompt tax avoidance and evasion and discourage saving and investment (Denk, 2012).

Table 4. Net wealth taxes in OECD countries, 2011

\begin{tabular}{|c|c|c|c|}
\hline Country & $\begin{array}{l}\text { Highest marginal } \\
\text { rate }\end{array}$ & $\begin{array}{l}\text { Assets } \\
\text { concerned }\end{array}$ & Country-specific details \\
\hline $\begin{array}{l}\text { France } \\
(2011)\end{array}$ & $1.80 \%$ & $\begin{array}{l}\text { Individuals' } \\
\text { assets }\end{array}$ & 7 brackets, top bracket starts at EUR 17 million \\
\hline \multirow[t]{2}{*}{$\begin{array}{l}\text { France } \\
(2012)\end{array}$} & $0.50 \%$ & $\begin{array}{l}\text { Individuals' } \\
\text { assets }\end{array}$ & 3 brackets, top bracket starts at EUR 3 million \\
\hline & & & $\begin{array}{l}\text { Exceptional tax decided in August } 2012 \text { puts back tax to } 2011 \text { rates and } \\
\text { brackets }\end{array}$ \\
\hline $\begin{array}{l}\text { France } \\
(2013)\end{array}$ & $1.50 \%$ & $\begin{array}{l}\text { Individuals' } \\
\text { assets }\end{array}$ & 6 brackets, top bracket starts at EUR 10 million \\
\hline Norway & $1.10 \%$ & $\begin{array}{l}\text { Individuals' } \\
\text { assets }\end{array}$ & Above NOK 770.000 \\
\hline Switzerland & $1.50 \%$ & $\begin{array}{l}\text { Individuals' } \\
\text { assets }\end{array}$ & Rates vary across cantons \\
\hline Iceland & $1.50 \%$ & $\begin{array}{l}\text { Individuals' } \\
\text { assets }\end{array}$ & Above ISK 70/100 million, temporary until 2013 \\
\hline Luxembourg & $1 \%$ & $\begin{array}{l}\text { Net } \\
\text { company } \\
\text { assets }\end{array}$ & \\
\hline
\end{tabular}

Source: Ernst \& Young (2011); Denk (2012).

The harmful effect on saving of very high METRs stemming from a combination of capital income and wealth taxes can be better understood if they are thought of as taxes on deferred consumption. In France, if taxpayers subject to the highest marginal rate of the net wealth tax decide not to consume today but to save and consume their labour income 30 years later, the real value of their savings and thus their purchasing power will be more than one third lower at that point. By contrast, with the earlier assumptions, the real value of their savings would increase by more than $10 \%$ in the absence of the wealth tax and by $80 \%$ if there were no capital income or wealth taxes. France's capital income tax on deferred consumption and the combination of capital income tax and wealth tax are the steepest in the OECD for high-income earners (Table 5). In practice, there exists a wide range of METRs because of the many loopholes, especially those for savings products. 
Table 5. The real value of savings (deferred consumption) after 30 years, 2011

\begin{tabular}{|c|c|c|c|c|c|}
\hline & \multicolumn{5}{|c|}{ First year $=1$} \\
\hline & $\begin{array}{l}\text { No tax on } \\
\text { capital income }\end{array}$ & $\begin{array}{c}\text { Tax on } \\
\text { capital income }\end{array}$ & & $\begin{array}{c}\text { No tax on } \\
\text { capital income }\end{array}$ & $\begin{array}{l}\text { Tax on } \\
\text { capital income }\end{array}$ \\
\hline Australia & 1.79 & 1.06 & Italy & 1.79 & 1.42 \\
\hline Austria & 1.79 & 1.34 & Japan & 1.79 & 1.42 \\
\hline Belgium & 1.79 & 1.51 & Korea & 1.79 & 1.42 \\
\hline Canada & 1.79 & 1.34 & Luxembourg & 1.79 & 1.60 \\
\hline Chile & 1.79 & 1.19 & Mexico & 1.79 & 1.42 \\
\hline Czech Republic & 1.79 & 1.51 & Netherlands & 1.79 & 1.26 \\
\hline Denmark & 1.79 & 1.34 & New Zealand & 1.79 & 1.29 \\
\hline Estonia & 1.79 & 1.40 & Norway & 1.79 & 1.29 \\
\hline Finland & 1.79 & 1.29 & with wealth tax & 1.79 & 0.94 \\
\hline France 2011 & 1.79 & 1.13 & Poland & 1.79 & 1.44 \\
\hline with wealth tax & 1.79 & 0.66 & Portugal & 1.79 & 1.40 \\
\hline France 2013 & 1.79 & 0.88 & Slovak Republic & 1.79 & 1.44 \\
\hline with wealth tax & 1.79 & 0.57 & Slovenia & 1.79 & 1.42 \\
\hline Germany & 1.79 & 1.34 & Spain & 1.79 & 1.40 \\
\hline Greece & 1.79 & 1.60 & Sweden & 1.79 & 1.26 \\
\hline Hungary & 1.79 & 1.49 & Switzerland & 1.79 & 1.19 \\
\hline Iceland & 1.79 & 1.60 & with wealth tax & 1.79 & 0.77 \\
\hline with wealth tax & 1.79 & 1.03 & Turkey & 1.79 & 1.51 \\
\hline Ireland & 1.79 & 1.26 & United Kingdom & 1.79 & 1.42 \\
\hline Israel & 1.79 & 1.34 & United States & 1.79 & 1.26 \\
\hline
\end{tabular}

Note: The calculations follow the methodology used by Denk (2012). The index on the real stock of savings shows the evolution after 30 years compared to the first year where the index $=1$. Top marginal tax rates (where applicable) are used for the calculations.

Source: OECD calculations.

\section{Residential housing enjoys considerable tax advantages}

Real estate enjoys preferential tax treatment compared to non-housing investment. The same holds true for home ownership relative to investment in rentals. The sources of non-neutrality are: $i$ ) imputed rent, the service that the owner receives from living in his property, is not taxed; $i$ ) capital gains on primary residences are not taxed; iii) government provides subsidies for investment in private rental housing; and $i v$ ) only $70 \%$ of the net value of the primary residence enters the tax base of the wealth tax, while other financial and real assets are assessed at full value. On the other hand, the standard VAT is levied on the sale of new homes, which largely removes another potential source of non-neutrality related to the fact that the consumption of housing services is not subject to VAT.

The first-best option to re-establish tax neutrality for housing would be to tax imputed rents at market value, which could be measured relatively easily, especially in cities, as the private rental market accounts for about $20 \%$ of the dwelling stock. Levying a tax on the market value of primary and secondary homes would do a similar job, even though this approach assumes that the price-to-rent ratio is homogeneously distributed geographically. In principle, the local property tax (taxe foncière) is based on properties' rental values and thus implicitly taxes imputed rents. But the current taxe foncière is based on values obtained from cadastral registries, which were last updated only in the mid-1970s. The previous Survey recommended regular updates of these values to ensure a more realistic base for property taxes. Updating the system on a regular basis could turn this property tax into a direct tax on imputed rents. In such a case, actual rents from rental housing should not be taxed. A second complication is that the taxe foncière is determined at the local level. In order to make it work as a nation-wide tax on imputed rents, it should have a minimum uniform rate country-wide and be aligned with taxes on capital income from other sources. 
Furthermore, the tax-free capital gains on primary residences should be aligned with capital gains due on other assets. Capital gains on secondary residences or rental real estate are fully exonerated from taxes if the property is owned for 30 years (compared to 15 years prior to 2012). The current system correctly allows the deduction of transaction and investment costs (including quality upgrades and additions but excluding maintenance, renovation and repair) from the tax base. Taxing capital gains on principal residences may discourage mobility, thereby creating lock-in effects. To circumvent this problem, the payment of capital gains taxes should be deferred if the receipts from the sale are used to buy another principal residence, in which case capital gains taxes should be payable on succession.

\section{Improving the taxation of the transfer of capital}

A final part of capital taxation concerns capital transfers. Taxes levied on transactions can be split into two broad groups: $i$ ) the purchase and sale of capital goods; and $i$ ) the transfer of capital goods without any monetary compensation in the form of a bequest or gift. Taxes on the commercial transfer of financial assets are low, even though the new tax of $0.2 \%$ on transactions levied since August 2012 can potentially create large distortions in resource allocation. But transaction taxes and notary fees are very substantial for real estate (see the previous Survey). It is widely recognised that transaction costs are detrimental for economic growth because they discourage the optimal re-allocation of resources in the face of a changing economic environment. Lock-in effects caused by high real estate transactions costs could lead to reduced residential mobility and thus to sluggish labour-market adjustments. It would therefore be desirable to reduce transfer taxes on the sale of property by shifting to other less harmful types of taxes.

As far as taxes levied on bequests and gifts are concerned, two major issues deserve discussion. First, a major justification for inheritance taxes is to reduce the inequality of opportunities and ex post income inequality. French inheritance taxes are strongly progressive and concern mostly very wealthy individuals. Inheritance taxes can also ensure that receiving a large bequest does not alter economic incentives by reducing the recipient's labour supply. Therefore, unplanned bequests could, in principle, be taxed at a rate of $100 \%$ without having any influence on the receiver's economic behaviour. But if bequests are planned in advance, a very high tax rate may discourage people from leaving bequests.

Second, from a more practical viewpoint, inheritance taxes should be coordinated with gift taxes because taxes on bequests could be potentially avoided by planning bequests through inter vivos transfers. In France, exactly the same brackets and marginal rates apply for bequests and gifts to children. For more distant relatives taxes on bequests are not only at least as high as for children, but gifts are more heavily taxed than bequests (Table 6). Currently, children can receive from their parents a tax-free bequest or gift below a threshold of 100000 euros (just lowered from 156000 euros) every 15 years. After that, another period of 15 years starts with the same amount of tax-free bequest or gift. But the objective of reducing both income and wealth inequality would imply that gifts and bequests received over somebody's lifetime should be considered, whatever the source (whether parents or more distant relatives or friends). It is important that unrealised capital gains, on both financial and real assets, should be taxed at the moment of succession. 
Table 6. Top marginal rates on gifts and bequests in OECD countries, 2011

\begin{tabular}{|c|c|c|c|c|c|c|c|c|}
\hline & Inheritance & Gift & Inheritance & Gift & Inheritance & Gift & Inheritance & Gift \\
\hline & \multicolumn{2}{|c|}{ Spouse } & \multicolumn{2}{|c|}{ Children } & \multicolumn{2}{|c|}{ Brothers \&sisters } & \multicolumn{2}{|c|}{ Nephews \& nieces } \\
\hline Australia & 0 & 0 & 0 & 0 & 0 & 0 & 0 & 0 \\
\hline Austria & 0 & 0 & 0 & 0 & 0 & 0 & 0 & 0 \\
\hline Canada & 0 & 0 & 0 & 0 & 0 & 0 & 0 & 0 \\
\hline Chile & 25 & 25 & 25 & 25 & 30 & 24 & 24 & 24 \\
\hline Czech Republic & 2.5 & 5 & 2.5 & 5 & 6 & 12 & 6 & 12 \\
\hline Denmark & 0 & 15 & 15 & 15 & 15 & 36.25 & 40 & 36.25 \\
\hline Estonia & 21 & 21 & 21 & 21 & 21 & 21 & 21 & 21 \\
\hline Finland & 16 & 16 & 16 & 16 & 32 & 32 & 32 & 32 \\
\hline France & 0 & 0 & 45 & 45 & 45 & 55 & 55 & 60 \\
\hline Germany & 30 & 30 & 30 & 43 & 43 & 43 & 43 & 43 \\
\hline Greece & 10 & 10 & 10 & 10 & 20 & 20 & 40 & 40 \\
\hline Hungary & 21 & 21 & 0 & 0 & 30 & 30 & 40 & 40 \\
\hline Iceland & 5 & 5 & n.a. & n.a. & n.a. & n.a. & n.a. & n.a. \\
\hline Ireland & 0 & 0 & 30 & 30 & 30 & 30 & 30 & 30 \\
\hline Italy & 4 & 4 & 4 & 4 & 6 & 6 & 6 & 6 \\
\hline Japan & 50 & 50 & 50 & 50 & 50 & 50 & 50 & 50 \\
\hline Korea & 50 & n.a. & 50 & n.a. & n.a. & n.a. & n.a. & n.a. \\
\hline Luxembourg & 16 & 4.8 & 15 & 1.8 & 28.8 & 6 & 48 & 8.4 \\
\hline Mexico & 0 & 0 & 0 & 0 & 0 & 0 & 0 & 0 \\
\hline Netherlands & 20 & 20 & 20 & 20 & n.a. & n.a. & n.a. & 20 \\
\hline New Zealand & 0 & 0 & 0 & 0 & 0 & 0 & 0 & 0 \\
\hline Norway & 0 & 0 & 10 & 10 & 15 & 15 & 15 & 15 \\
\hline Poland & 7 & 7 & 7 & 7 & 7 & 7 & 12 & 12 \\
\hline Portugal & 0 & 0 & 0 & 0 & 0 & 0 & 0 & 0 \\
\hline Slovak Republic & 0 & 0 & 0 & 0 & 0 & 0 & 0 & 0 \\
\hline Slovenia & 0 & 0 & 0 & 0 & 14 & 14 & 14 & 14 \\
\hline Spain & n.a. & 34 & n.a. & 34 & n.a. & 34 & n.a. & 34 \\
\hline Sweden & 0 & 0 & 0 & 0 & 0 & 0 & 0 & 0 \\
\hline Turkey & n.a. & 15 & n.a. & 15 & n.a. & 30 & n.a. & 30 \\
\hline United Kingdom & n.a. & 0 & n.a. & 0 & n.a. & 0 & n.a. & 0 \\
\hline United States & n.a. & 0 & n.a. & 35 & n.a. & n.a. & n.a. & n.a. \\
\hline
\end{tabular}

Source: Ernst \& Young, International Estate and Inheritance Guide 2012, http://www.ey.com/GL/en/Services/Tax/International-Estate-and-Inheritance-Tax-Guide---Country-list, retrieved in June 2012.

\section{Reduced VAT rates are an inefficient way to redistribute income}

Taxes on goods and services are an important part of the French tax system, accounting for about one fourth of total tax revenues. Given that the value of a good or service depends on the flow of benefits it provides, consumption taxes should be concerned with taxing these benefits (and not the transaction itself) either upfront when the good or service is first sold or annually, in line with the flow of benefits. The value added tax (VAT) is generally considered to be a good tax, and the use of excise duties can also be justified if they aim to internalise negative externalities triggered by the consumption of specific goods and services. The OECD, including in the previous Survey, has long advocated a VAT system based on a uniform rate and a broad tax base rather than one with multiple rates and a narrow base.

The most common justification of reduced rates for essential goods and services is based on equity grounds: those products primarily purchased by the poor should be taxed less. Another argument is that the average propensity to consume is higher for the poor and thus they pay more of their income in a single-rated flat VAT scheme. Empirical observations show that in France, rich households benefit from those rates to a much larger extent than poor households (Bozio et al., 2012). In addition, some reduced 
rates may be regressive, as for example in the case of restaurant meals and renting yachts. Micro simulations carried out by Ruiz and Trannoy (2008) for France show that reduced rates generate only a small amount of redistribution. Distributional objectives could be achieved more cost efficiently by considering the tax system as a whole rather than VAT in isolation. Therefore, reduced VAT rates should be eliminated. The very poor would be protected by the fact that social transfers (including the RSA) and minimum wages are indexed to inflation. If needed, further compensation could be provided by increasing means-tested lump-sum payments to reduce inequality at a lower cost (Mirrlees Review, 2011; OECD, 2011e). Such a system operates in Canada, where low- and modest-income households get a partial refund of estimated sales and value added taxes on their income taxes.

As of January 2014, the intermediate VAT rate of 7\% will increase to $10 \%$, while the reduced rate of $5.5 \%$ will drop to $5 \%$ and the standard rate will go up to $20 \%$ from $19.6 \%$. The effective VAT rate is lower than the standard rate not only because of the numerous reduced rates but also because financial intermediation, unpaid domestic services and non-market educational, healthcare and social welfare services are not subject to VAT. It is difficult to levy VAT on domestic and non-market services. VAT on imputed and actual rents is imposed via VAT paid on new housing.

\section{A large dispersion of implicit carbon prices but good progress in internalising local pollution}

To the extent that damage done to the environment is not irreversible, the costs of negative externalities stemming from greenhouse gas (GHG) emissions and localised environmental pollution should be fully internalised in the final price of polluting products by setting taxes equal to the social costs of pollution. The two waves of the Grenelle programme launched under the Sarkozy presidency included a great number of price and non-price instruments aimed at mitigating GHG emissions and reducing local air and water pollution. Nevertheless, the current set-up is not cost efficient. Estimated carbon prices implied by existing taxes on various energy sources, including automotive fuel, heating oil, natural gas and coal, vary widely.

Ideally, a single carbon price should be imposed across sectors (and countries) to reduce GHG emissions where it is the cheapest to do so (OECD, 2011e). This condition is generally not met, and in some cases the implicit price of $\mathrm{CO}_{2}$ is even quite negative (Figure 8). The tax system not only differentiates between different energy sources, but a large number of tax exemptions and reductions apply for a given energy source. A case in point is the excise tax exemption granted to fuel used for fishing vessels and maritime navigation and reductions for trucks, large agricultural vehicles, buses and taxis. However, the kilometric levy on heavy goods vehicles, which should take effect throughout France in July 2013, will cover more of the external costs associated with road freight traffic. In all, the dispersion of French carbon prices is relatively high but remains close to the average of the OECD countries for which this indicator can be calculated (Figure 8). Therefore, the government should seek to equalise implicit and explicit carbon prices across emission sources so as to minimise the cost of abatement. 
Figure 8. Carbon price dispersion across OECD countries and within France, 2010-Q4

EUR/tonne of $\mathrm{CO}_{2}$

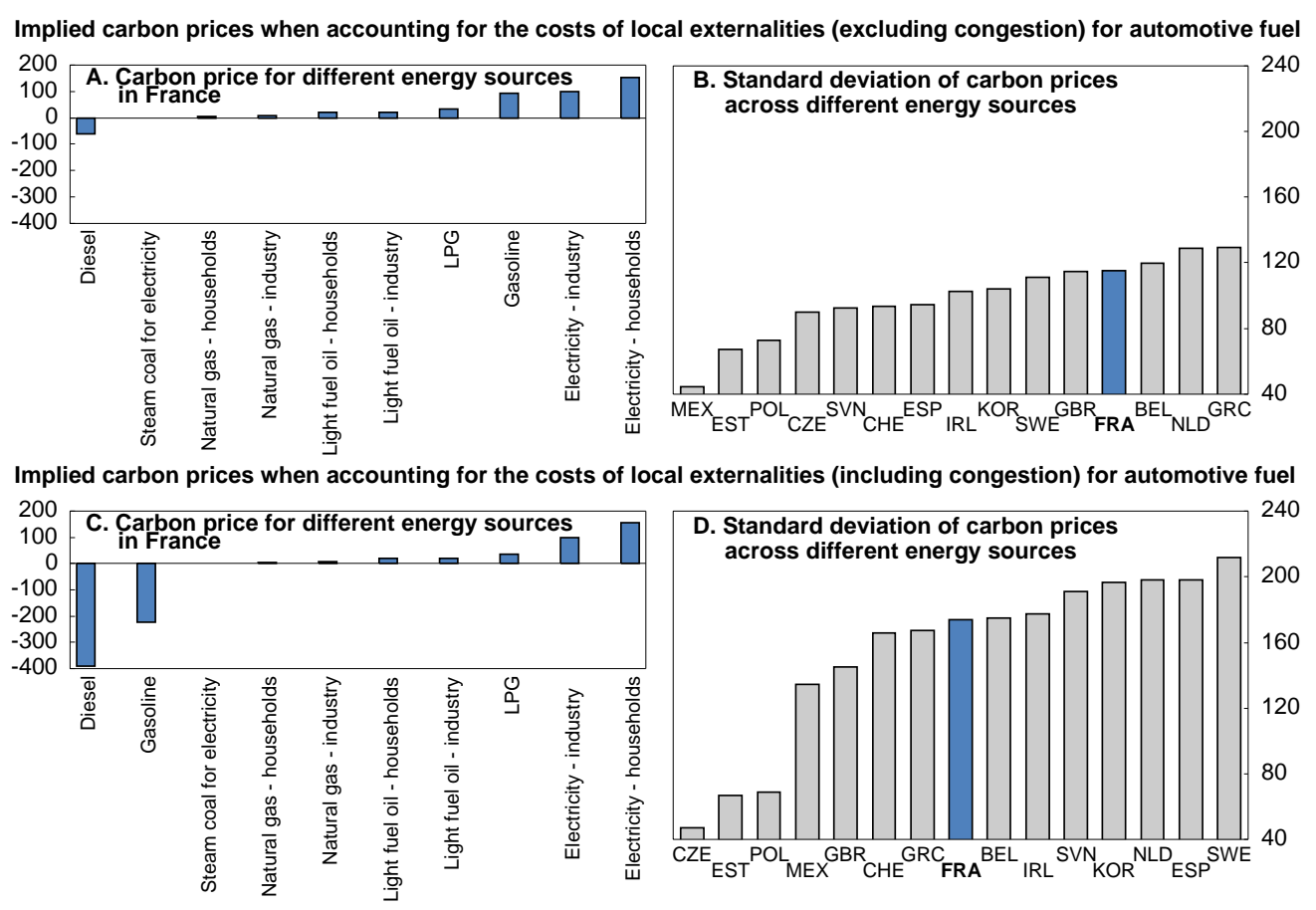

1. The implicit carbon tax level is obtained as follows: the starting point are excise taxes, from which two types of costs are deducted: i) the external costs of air pollution, noise and accidents; and ii) the external cost of the forms of pollution listed in i) plus that of congestion, standardised in EUR/tonne of $\mathrm{CO}_{2}$. See Figure 4.4 of the Economic Survey of France, 2011.

Source: OECD calculations based on the OECD Economic Surveys of France 2011 and of Poland 2012.

An additional weak point of current climate-change mitigation policies is the often substantial overlap between different instruments, which can increase the costs of achieving policy objectives. The two main examples are the upfront fees charged for passenger car purchases, in particular the bonus-penalty system introduced in 2008 and extended to hybrid and electric cars in mid-2012, and the compulsory feed-in tariffs for renewable energy sources. These tariffs represent a tax on final electricity consumers and overlap with both the implicit carbon prices contained in taxes on fossil energies and the price signal from the European emissions trading scheme (EU-ETS). The upfront financial penalty imposed by the bonus-penalty system may be justified if the price elasticity of fuel consumption is low and if myopic behaviour and asymmetric information would prevent consumers from fully perceiving the reduced lifecycle consumption of more carbon-efficient cars. But there is little economic justification for maintaining the bonus part, which financially rewards a negative global and local externality since even very low-emission cars cause a negative externality (OECD, 2011e). Even if the bonus-penalty system has led to a reduction in unit emissions and fuel consumption in new vehicles, a recent study (Givord and d'Haultfoeuille, 2012) shows that the bonus part increases global GHG emissions through an expansion of the car fleet and the so-called rebound effect (increased mileage).

Feed-in tariffs targeted at renewables overlap with price signals provided by the EU-ETS and are therefore costly. But actively supporting renewables may be necessary if France wants to comply with renewables targets determined at the EU level or because of learning-by-doing and infant-industry arguments. Yet supporting renewable energy should be done in a cost-efficient and technology-neutral way by providing each technology the same amount of support per tonne of $\mathrm{CO}_{2}$ avoided. Abatement costs implied by feed-in tariffs fell significantly between 2009 and 2011, in particular for solar energy, and the dispersion of technology-specific abatement costs shrank sharply. Yet, these costs remain high for solar 
energy and still vary substantially. This holds true even in international comparison, in which France is at the higher end of the scale (Figure 9). The government should further adjust and render abatement costs more homogeneous to achieve its renewables targets cost efficiently.

Figure 9. Dispersion of carbon abatement costs implied by indirect support schemes (feed-in tariffs, green certificates) ${ }^{1}$

EUR/tonne of $\mathrm{CO}_{2}$
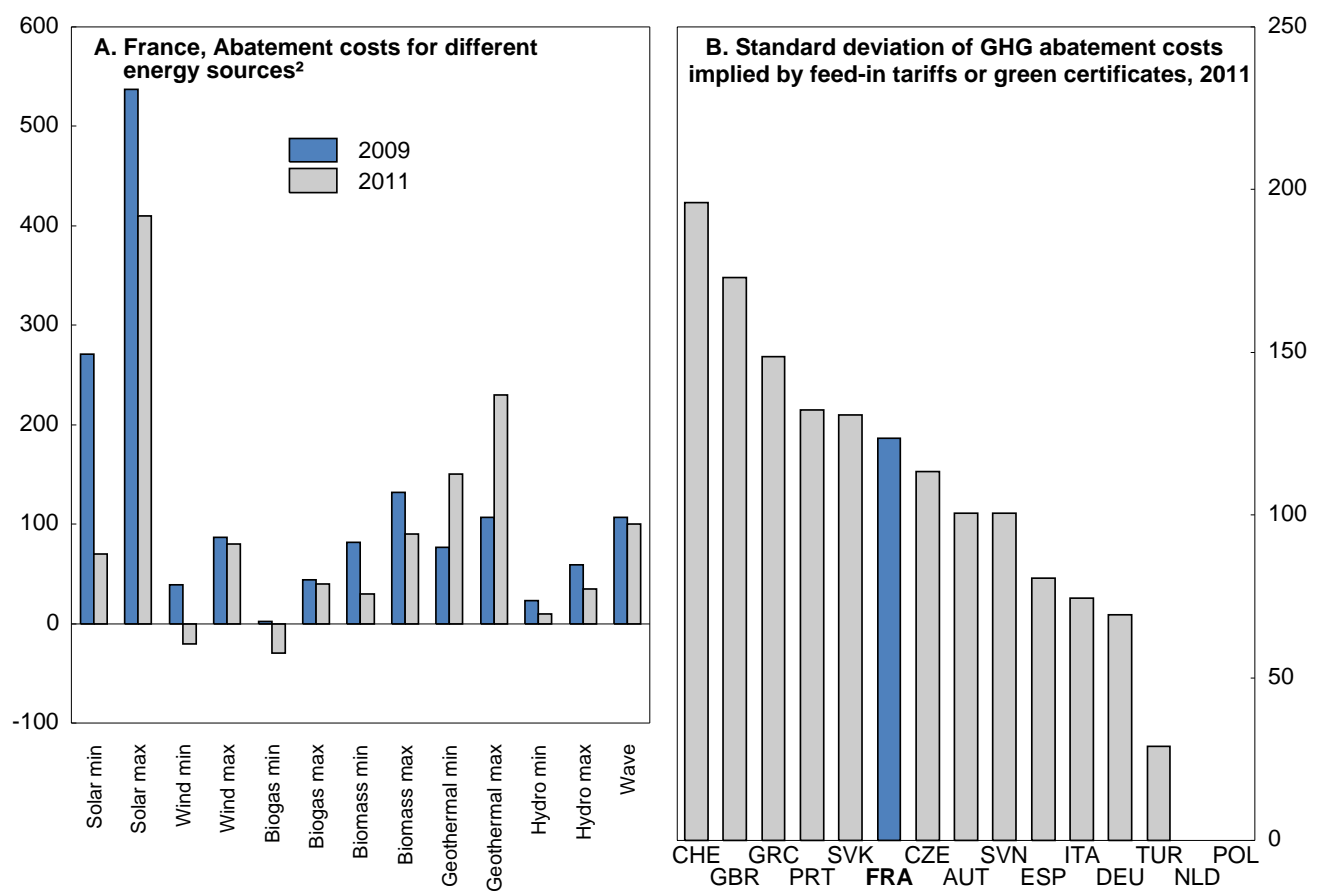

1. Abatement costs are calculated against a benchmark of coal-fired power plants.

2. Min and max denote abatement costs based on the lowest and highest feed-in tariffs for specific energy groups.

Source: OECD calculations based on the OECD Economic Survey of Poland 2012.

With regard to the internalisation of local pollution, France has been making good progress in increasing the general tax on polluting activities (TGAP) for dumping and burning waste. The tax on landfill was raised to 20 euros per tonne in 2010 , broadly in line with estimated external costs, and is expected to be boosted to 40 euros by 2015 . The TGAP aligns taxes on incineration with social costs. In contrast, the external costs of pesticide and fertiliser use is currently only partially internalised or not at all, as emphasised in the previous Survey (OECD, 2011e). So the government should think about the introduction of a tax on fertilisers and raising the tax on pesticides to match estimated external costs. With regard to air pollution, the 2013 budget raised TGAP rates on sulphur oxide and other compounds, lowered the application threshold and extended the TGAP to five new pollutants that can be found in the air (benzene, arsenic, selenium, mercury and polycyclic aromatic hydrocarbons). The government has announced that it intends to raise additional environmental tax revenues of EUR 3 billion by 2016, but the details have not yet been made public.

\section{The transfer system should be simplified}

The French cash transfer system is the cornerstone of the system of income redistribution, as it channels roughly $70 \%$ of redistributed income. Social spending, including public expenditure on family, housing, unemployment, survivor and disability benefits and active labour market policies (ALMPs), 
accounts for $10 \%$ of GDP, the seventh highest in the OECD (Figure 10, Panel A). But if old-age pensions and health-care spending are also taken into account, France becomes the top OECD spender, with the share of this wider but less comparable definition of social spending reaching $30 \%$ of GDP. With the exception of incapacity and miscellaneous social spending, in 2009 every subcategory of social spending represented a higher share of GDP in France than in the OECD average (Figure 10, Panel C). Looking at the respective shares of various social spending in total social spending reveals that France spends considerably more on old-age pensions and somewhat more on survivors' pensions, labour-market-related policies and housing than the average OECD country (Figure 10, Panel D).

\section{Figure 10. Social spending in France and the OECD, 2009}
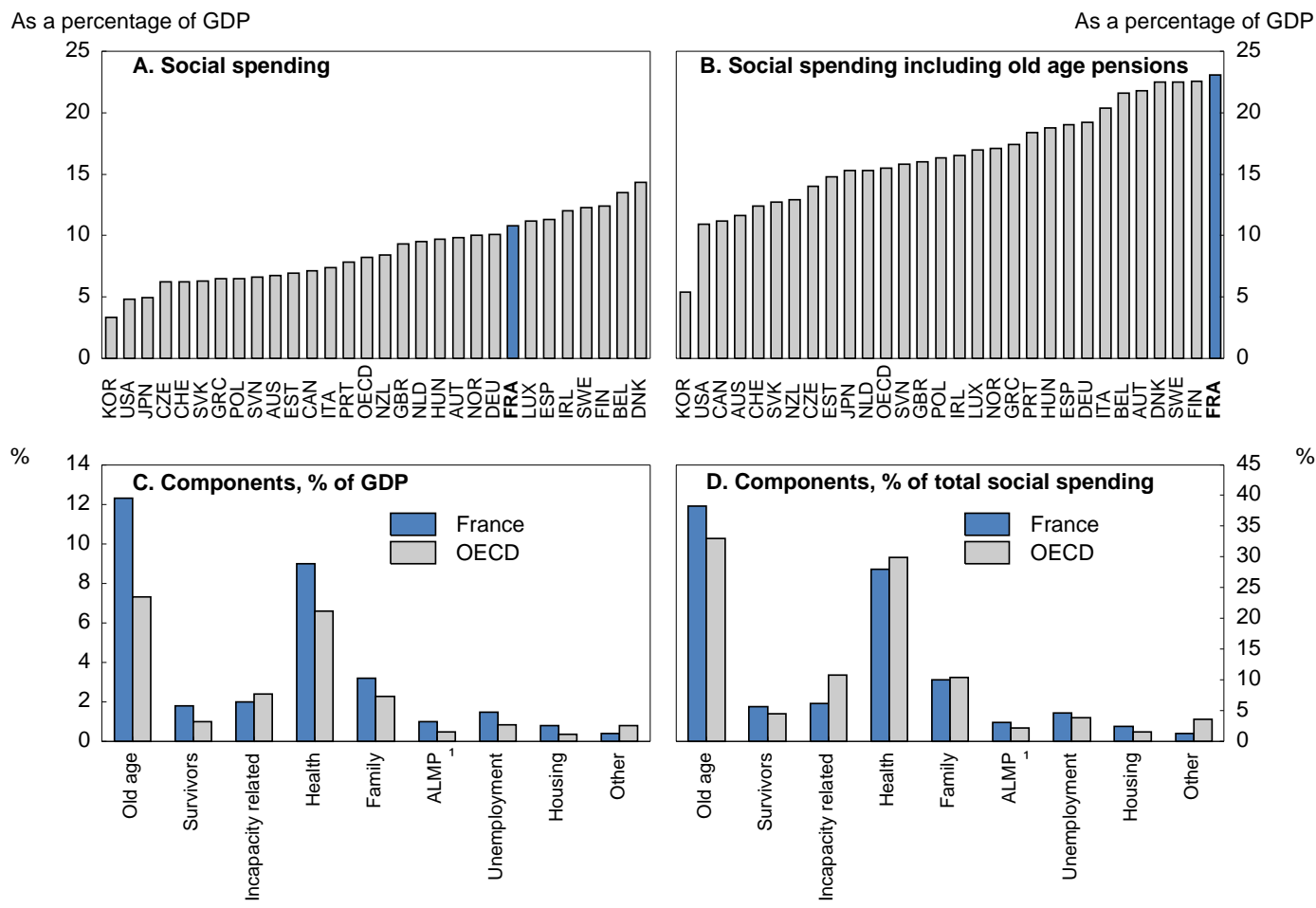

1. Active labour market policy.

Source: OECD, Social Expenditure (SOCX) database.

The system is complex, with more than 60 spending programmes (in addition to the 90 -odd old-age and survivors' pension schemes). Complexity increases administrative costs, and the resulting lack of transparency poses a barrier for potential beneficiaries and reduces benefit take-up. There is also a general problem regarding the system's overall consistency because some transfers overlap with others and they are not always designed jointly, sometimes because of coordination problems among different levels of government. Decisions are not always based on detailed cost evaluations. For instance, the cutback in places in the public pre-school education system for 2-3 year-old children (école maternelle) for cost-saving reasons was largely offset by more places in alternative forms of public pre-school education (such as halte-garderie and crèche), which are actually more costly to public finances. Objectives of spending programmes can be contradictory. For instance, family policies seek to improve conditions for pre-school childcare to allow parents (mostly women) to return quickly to the labour market, whereas the parental leave allowance (complement de libre choix d'activité, CLCA, paid subject to certain work-related conditions) to those deciding to stay at home with young children give strong incentives, especially for (low-skilled) low-income individuals to stay at home for many years, which considerably reduces their 
chances to ever return to work. Moreover, the revenue base and thresholds of means-tested transfers are not always harmonised, and the period for which income is considered can differ. For instance, past-quarter income is the basis of the incentive part of the RSA, income lagged one year serves as a basis for PPE (prime pour l'emploi), and income lagged two years is used to determine eligibility for housing subsidies.

Against this backdrop, a strong case can be made for a simplified cash transfer to households. One avenue to explore (currently in an experimental stage in the United Kingdom) would be to combine all means-tested and non-means-tested benefits into a single benefit in a budget-neutral way, improving the system's transparency and eliminating its inconsistencies. This single benefit should also include housing benefits, provided the landlord-tenant relationship is rebalanced as recommended in the previous Survey.

\section{Conditionality of unemployment benefits should be strengthened}

Public spending on unemployment benefits and active labour market measures (ALMPs) as a share of GDP are relatively high in France, but it ranks lower if spending on ALMPs is measured per unemployed relative to per capita GDP (Figure 11). Reasonably high net replacement rates offered by unemployment benefits, such as France's 70\%, coupled with a fairly generous maximum duration are viewed as justified to ensure that job seekers can find a position that fits their skills. Active measures, especially retraining programmes, may be necessary to help unemployed individuals update their human capital or acquire new skills, which would improve their job-market prospects. But benefits should be combined with incentives to shorten unemployment spells and avoid long-term unemployment, which is costly to the individuals concerned, public finances and society.

Figure 11. Active labour market policies and unemployment benefits ${ }^{1}$

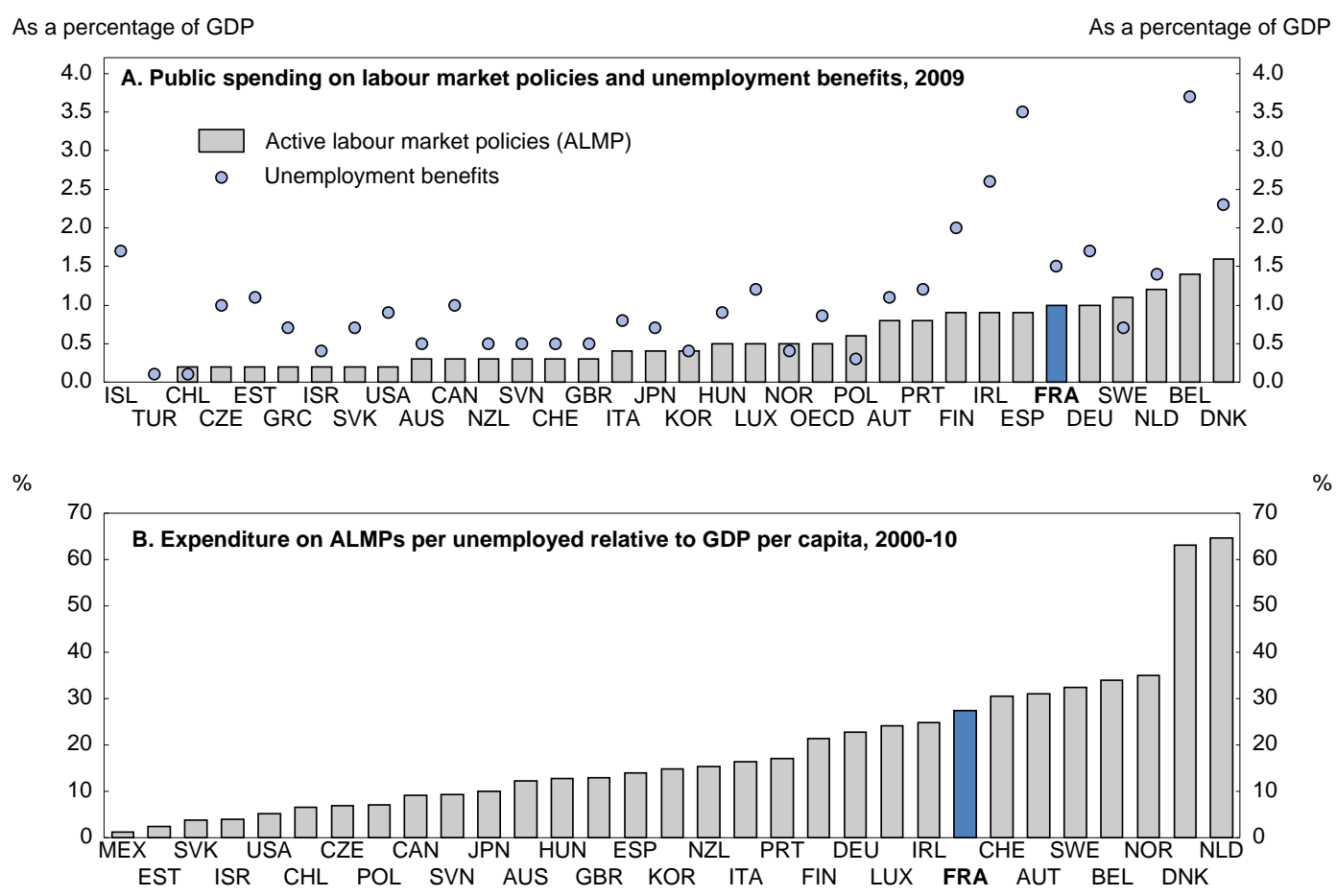

1. Active labour market policies include public employment services and administration, training, employment incentives, integration of the disabled, direct job creation, and start-up incentives.

Source: OECD, Social Expenditure (SOCX), Employment Policies/ALMP and Labour Force Statistics databases. 
When the economy recovers, the incentives embedded in the French system to return to work could be strengthened, without magnifying income inequalities, via degressivity and/or conditioning benefits on participation in active measures and the obligation of accepting "reasonable" job offers. First, the maximum duration of benefits is two years (three years for those aged 50 and above), and the replacement rate stays flat over this period. Long-term unemployment benefits (allocation de solidarité spécifique, ASS, and allocation équivalent retraite, AER) prolong that period considerably. The ASS is a long-term unemployment benefit that is very near to the level of the basic RSA, but it enables an accumulation of pension entitlements (see below). The AER, which is significantly higher than the ASS and basic RSA, is intended for those unemployed who have contributed long enough for a full pension but have not reached the minimum retirement age. Abolished in 2011, the AER is likely to be restored in 2013, under strict eligibility conditions, for persons born in 1952 or 1953. Care should be taken not to prolong this scheme, which encourages early departures from the labour market and is a drain on public finances, and to provide a bonus (surcote) instead.

Empirical evidence for several countries suggests that jobseekers tend to intensify search efforts as they come close to the end of benefit eligibility. But as jobs are less plentiful during downturns, duration and the amount of benefits should depend on the local unemployment rate. Second, the METR implied by the withdrawal of the unemployment benefits varies from $75 \%$ to $90 \%$ for a wide range of income and family situations (Table 2). Therefore, it is important to effectively condition benefits on active job search and participation in retraining programmes. According to a 2008 law, non-acceptance of a second "appropriate" job offer is sanctioned, in principle, by the withdrawal of the benefits for two months. The lack of available data makes it impossible to dispel suspicions that benefits are in fact rarely withdrawn when job offers are refused. Introducing degressivity, i.e. a decline in the unemployment benefit during the spell, would strengthen incentives to find a new job, in particular because the reservation wage declines with the chances of finding work again and when the end of the benefit period approaches, just as does conditioning unemployment benefits on active job search. But gradual degressivity can be complex to administer if there is overlap between unemployment benefits and other social transfers. However, a steeper drop, with two steps, for example, over the duration of eligibility for payments, could avoid this problem. In fact, this form of degressivity has been implemented in many OECD countries (Table 7). Whereas according to Dormont et al. (2001) the degressivity with which France experimented in the 1990s did not appear to have any positive impact on getting people back to work, Prieto (2000) suggests that a more abrupt drop in benefits increases returns to work more than a gradual decrease.

Table 7. Degressivity of unemployment benefits in Europe, 2010

For a 40-year old (where benefits are conditional on work history, the table assumes a long and uninterrupted employment record)

\begin{tabular}{lll}
\hline & \multicolumn{2}{c}{ Payment rate (\% of earnings base) } \\
\cline { 2 - 3 } & Initial & At end of legal entitlement period \\
\cline { 2 - 3 } Belgium & 60 & 53.8 (after 1 year) \\
Czech Republic & 65 & $50-45$ (after 2 and 4 months) \\
Estonia & 50 & 40 (after 101 days) \\
Italy & 60 & 50 after 6 months \\
Netherlands & 75 & 70 (after 2 months) \\
Poland & Fixed amount 30\% of average wage & Fixed amount 23\% of AW (after 3 months) \\
Slovenia & 70 & 60 (after 3 months) \\
Spain & 70 & 60 (after 6 months) \\
Sweden & 80 & 70 (after 9 months). 65 (after 14 months) \\
Latvia & 65 & 32.5 after 7 months \\
Lithuania & $40+$ fixed amount of LTL 350 per month & 20 after 3 months \\
\hline
\end{tabular}

Source: www.oecd.org/els/social/workincentives 
Furthermore, the public employment service (PES), Pôle emploi, is well placed to administer the unemployed and deal with benefit payments, but it struggles to carefully monitor jobseekers and provide them with tailored training and job solutions. For instance, a counsellor monitors an average of 160 jobseekers (Pôle emploi, 2012), which is two to three times higher than in the United Kingdom. Relative to the number of jobseekers, the personnel of the French PES is half of that in Germany and the United Kingdom (Inspection Générale des Finances, 2011). Since 2009 Pôle emploi has faced competition from private job-placement agencies. A recent report commissioned by the Senate argues that a more intense monitoring would necessitate more resources (Alduy, 2011). The recent report Dares-Pôle emploi (2013) shows that people who are closely assisted by a private organisation get more intensive and personalised assistance, but that back-to-work and back-to-long-term-work rates are higher for the unemployed who are assisted by Pôle emploi than for those assisted by private agencies. However, no concise information is available on the costs of placing a jobseeker permanently in a new job. Overall, better data should be collected with regard to cost effectiveness. Australia could be a useful benchmark of how performance-related contracts with private providers, which would increase competition and sort out low-quality firms, can help place benefit recipients into permanent jobs in a cost-efficient way (Behaghel et al., 2012; OECD, 2012b). The experiments in outsourcing job-placement services carried out in the Netherlands also show the importance of the type of contracts concluded and the incentives given to outside operators.

Pôle Emploi's new three-year strategic plan (Objectif 2015), decided in July 2012, includes progress in terms of performance measurement and better targeting at those in difficult situations. It calls for staff redeployments and additional resources so that the advisers in charge of helping the job-seekers least equipped for the labour market carry a case load of no more than 70 persons. Yet, there are also three burning coordination and efficiency-related issues that should be addressed. First, the unemployment benefit system, UNEDIC, is run by the social partners for historical reasons: UNEDIC was founded by the social partners in 1958. The main parameters of the system are decided by the trade unions and employer organisations. The government's only power is to refuse to sign the convention: this has happened only once over the last 40 years. UNEDIC is independent from the State, and the social security administration and can issue its own bonds to finance it deficits. But the State explicitly guaranteed UNEDIC's bond issuance in 2011 and 2012 (Standard \& Poor's, 2012) and, more generally, the debt of UNEDIC enjoys a virtually explicit State guarantee. Second, training programmes offered to the unemployed are provided by local governments (regions), Pôle emploi and the State. A failure of co-ordination among these actors may easily lead to badly targeted programmes (CNFPT, 2010). Pôle Emploi's 2015 strategic plan includes a number of measures to enhance the effectiveness of training services. Finally, the integration of ANPE and ASSEDIC into Pôle emploi has not yet reaped its full benefits, because of difficulties in fully automating back-office paperwork (Alduy, 2011). Overall, the government should seek to improve the cost effectiveness of the system and better enforce and strengthen activation policies.

\section{Social transfers should be focused on getting beneficiaries into jobs}

The active solidarity income (RSA) is the cornerstone of France's broad-based social assistance. Its introduction in 2009 helped streamline the complex web of social benefits, an encouraging step forward. The basic scheme (RSA socle) provides basic financial support for jobless individuals according to their household income and composition. Household income is assessed on a very broad basis, including all other regular benefits (housing, family, etc). One of the aims of the 2009 reform was to combine social assistance with a back-to-work support strategy by strengthening conditionality: benefit recipients were meant to be obliged to actively look for a job and enrol in retraining and other ALMPs (OECD-ILO, 2011). Non-compliance with regularly meeting with social and job counsellors or participating in active programmes results in the suspension of benefit payments. But implementation of the incentive element remains limited: some RSA recipients are not advised at all, and monitoring is insufficient. Instead of a single counsellor in Pôle emploi, basic RSA recipients are advised by other bodies as well, including the 
social security administration and local governments (OECD-ILO, 2011; Bourguignon, 2011). At the beginning of 2012, sanctions for non-compliance with job-search obligations by basic RSA recipients were toughened. This measure is welcome, but whether it is applied systematically remains to be checked.

The financial work incentive (RSA activité) is a bonus of about $60 \%$ for every euro earned below a ceiling and decreasing linearly above that. It eliminates the previous poverty trap, which was the result of having any extra income lead to a proportionate reduction in social benefits. Yet, the overall result of the reform on employment is uncertain, and enrolment rates remain low for activity RSA. Nevertheless, Bourguignon (2011) shows that the RSA alleviates poverty substantially.

The specific solidarity allowance (allocation de solidarité spécifique, ASS), a long-term unemployment benefit conferring entitlement to a retirement pension, is targeted in general at unemployed people after the expiry of their unemployment benefits and at specific occupational groups (artists, seamen and dockworkers) in case of unemployment in the absence of unemployment insurance eligibility. ASS is conditional on five years of work during the 10 years preceding the end of the employment contract and is household means-tested. It requires job search and, like the RSA, offers a safety net while at the same time allowing the accumulation of benefits and income so as to encourage a return to work. But a major drawback of ASS is that it can reduce the labour supply of certain older workers, especially low-skill/low-income workers. If somebody becomes unemployed at the age of 52 and has worked long enough, after having received unemployment benefits for three years, (s)he may receive social benefits until retirement. The ASS is replaced by plain unemployment benefits for those aged 61 and over: those of this age coming to the end of their three years of unemployment benefits are entitled to continued unemployment benefits until they reach the minimum retirement age. Indeed, almost half of those receiving ASS in 2010 were aged 50 or over (DARES, 2012). While access to ASS is stricter than for $\mathrm{RSA}$, it is also more generous, in particular because it confers pension entitlements.

\section{Disability benefits are a potential channel of benefit substitution}

Strengthening work and activation requirements for social assistance and shutting down implicit channels of early retirement through unemployment benefits could give rise to benefit substitution towards incapacity benefits, for instance. Optimal policy design should therefore firmly maintain access conditions to disability pensions (Røed and Westlie, 2012). Disability pensions are naturally higher than income support from social assistance. Also, even though disability benefits are less generous than unemployment benefits, the lack of work and activation requirements could make them appealing. Public spending on incapacity benefits (disability pensions and sickness allowances) are relatively low in France (2\% of GDP), and the share of disability benefit recipients in the working-age population is also comparatively low, yet rising since the mid-1990s (Figure 12). Incapacity-related public spending consists primarily of passive measures (cash benefits). Flanking measures include anti-discrimination laws and a penalty for private and public companies in case of non-compliance with employment quotas for disabled people. That employers hire mostly only moderately disabled people is not surprising, given the absence of differentiation for the quota among different levels of disability (OECD, 2010; IZA, 2010). Inflows to disability pensions could be reduced in two ways. First, the length of sick leaves should be monitored carefully because an extended duration increases the probability of entering disability, and, in 2004 at least, the average duration of sick leave in France was among the highest in the OECD (OECD, 2005). Second, as in many other OECD countries, disability rates are higher for low-skill and older workers. Furthermore, the employment rate of disabled people is well below that of people without any disabilities, and disabled people, if they work at all, tend to hold part-time jobs. Hence, in contrast with current practise, ALMPs (including job counselling, training and education) should have a place in the disability policy mix, which would complement income security with work incentives. 

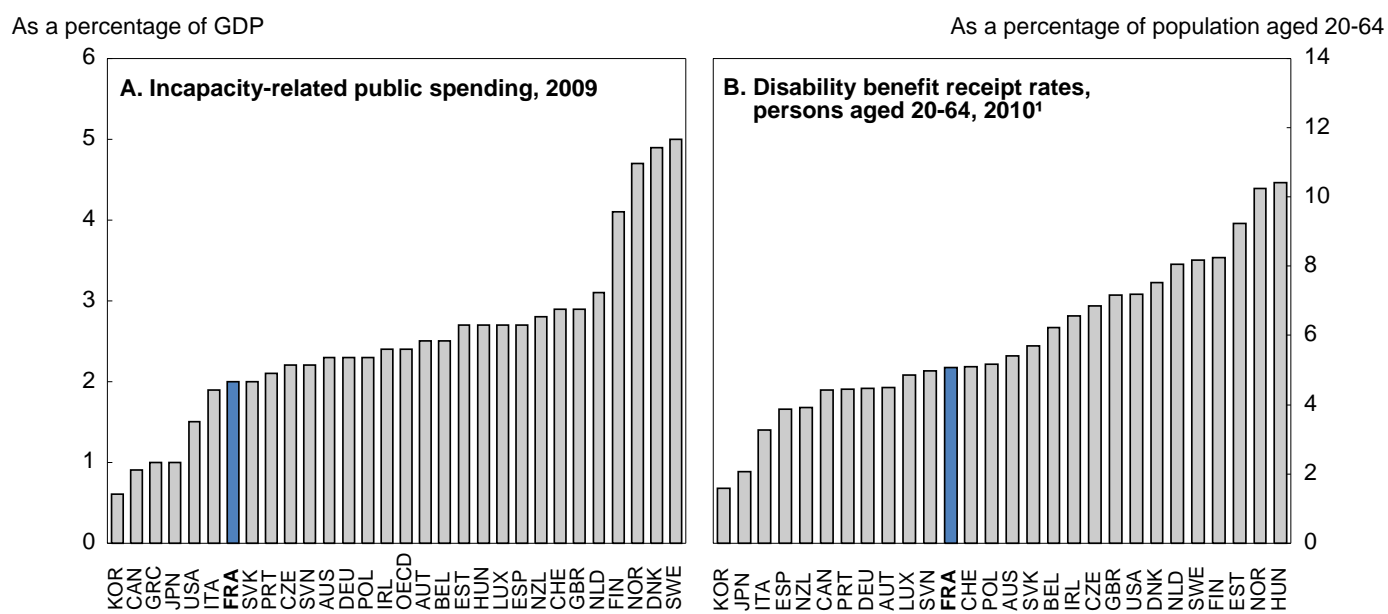

1. Or latest year available; 2007 for France.

Source: OECD, Social Expenditure (SOCX) database and OECD (2013), Mental Health and Work: Belgium.

\section{Family benefits are tilted towards those having at least three children}

Family policies embodied in family benefits seek to encourage people to have more children and aim to maintain living standards of families with children in accordance with horizontal equity. In this spirit, families with children should pay lower taxes because their living standards are lower compared to those of childless households with the same earnings. It is often argued that such a policy is regressive from a vertical equity point of view because it subsidises children more in wealthy families. However, horizontal equity can be achieved without increasing overall income inequality by taxing households without children at higher marginal rates than those with children. The empirical literature suggests that these monetary incentives, which combined with other family policies diminish the cost of raising children, have a tangible effect on fertility rates (D'Addio and Mira D'Ercole, 2005; Luci and Thévenon, 2012). Both the fertility rate and spending on family policies as a share of GDP are in fact high in France (Figure 13). Spending on family policies involves direct cash payments, numerous tax breaks and in-kind benefits. The two main fiscal measures used to achieve horizontal equity and thus reduce extra costs of having children are basing family taxation on the number of children and paying non-means-tested family allowances. In 2010 tax reductions for children and spouses cost more than 1\% of GDP and family allowances $0.6 \%$ of GDP.

Family support is tilted towards those having at least three children. For personal income tax, the first two children are allocated 0.5 part, while others are worth a full part in the calculation. The monthly family allowance is zero for one child, about 130 euros for two children, and more than 160 euros for each additional child. Means-tested benefit (complément familial) is available for families with three or more children older than three. It is noteworthy that other entitlements are also sensitive to numbers of children. For instance, both parents are entitled to a (non-taxable) $10 \%$ increase in pension benefits if they have raised three or more children. Families who have to move because of the arrival of a third child are also entitled to a moving allowance. 

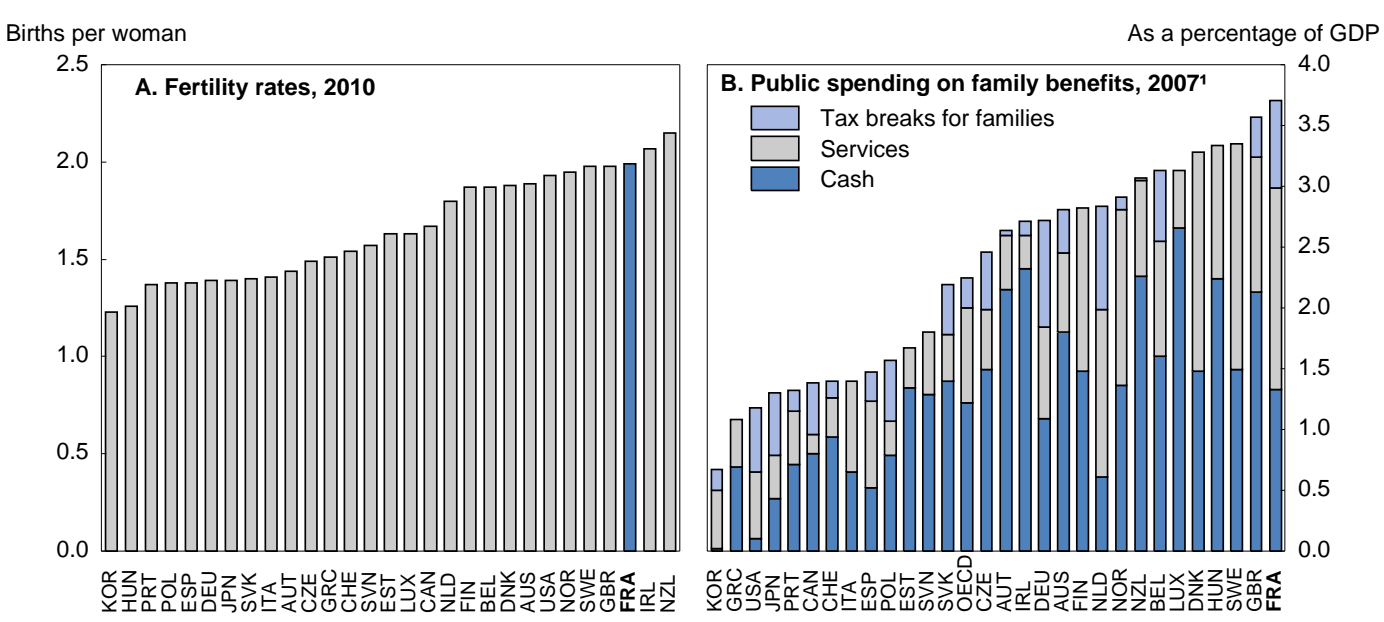

1. Public support included here concerns only that which is exclusively for families (e.g. child payments and allowances, parental leave benefits and childcare support). Spending recorded in other social policy areas such as health and housing support also assists families, but not exclusively, and is not included here.

Source: OECD Family database.

\section{The design of the parental leave allowance may push low-skill mothers into an inactivity trap}

Another important aspect of family policies is the granting of a parental leave allowance (CLCA) before and after birth and the access to pre-school childcare, which jointly determine whether and when women return to work. Maternity leave is 16 weeks ( 26 weeks from the third child). After maternity leave, parents have three options: $i$ ) staying at home with the newborn and receiving an allowance; $i$ ) employing a qualified nanny or putting the child in a private nursery and receiving direct cash payments and a tax credit on $50 \%$ of the nanny's employer SSCs; or iii) placing the child in a public nursery (crèche or halte-garderie), where children whose parents both work have preferential treatment. The two latter measures, backed by a lump-sum income-dependent benefit for young children (on top of the family allowance), clearly favour female labour market participation. Whereas enrolment rates of around $40 \%$ in formal pre-school childcare institutions for 0 to 2 year-old children are relatively high, there is scope to increase them further. Quality, reflected in the children-to-teaching-staff ratio for 0 to 3 year-olds, seems to be a problem (Figure 14). There is also anecdotal evidence that public nurseries for 0 to 3 year-olds are not evenly distributed geographically and not sufficiently targeted at low-income, single-parent households, who cannot benefit from tax advantages.

The design of the parental leave allowance (CLCA) may create an inactivity trap for low-skill (low-income) mothers by, in certain cases, offering them the benefit for six consecutive years: this flat amount can be received for six months for the first child and three years after the birth of the second and third children, provided they are born within, respectively, four and five years after the mother's last job. This can give the following birth pattern: first child in year $t$, second in $t+1$ and third in $t+3$. After six years spent at home, low-skill women may find it very difficult to return to the labour market (even though their job is kept in the company in which they worked before the birth of their first child). Indeed, the employment rate of low-skill women of childbearing age is low (Figure 4). The CLCA leads to an acceptable replacement rate for low-income individuals/families, but high-income earners' low replacement rate encourages an early return to one's former job. Admittedly, the current system has a mild incentive element for women to return to work more quickly after the second or third child: instead of staying at home three years with the third child, the mother can decide to stay only one additional year at home (reducing the six years to four), and receive a 30\% higher allowance in return. Overall, the duration 
of the CLCA should be shortened. A precondition of a shorter parental leave is an increase in places in nurseries available for children aged less than three.

Figure 14. Enrolment rates in formal pre-school childcare institutions and the ratio of children to teaching staff in formal daycare services
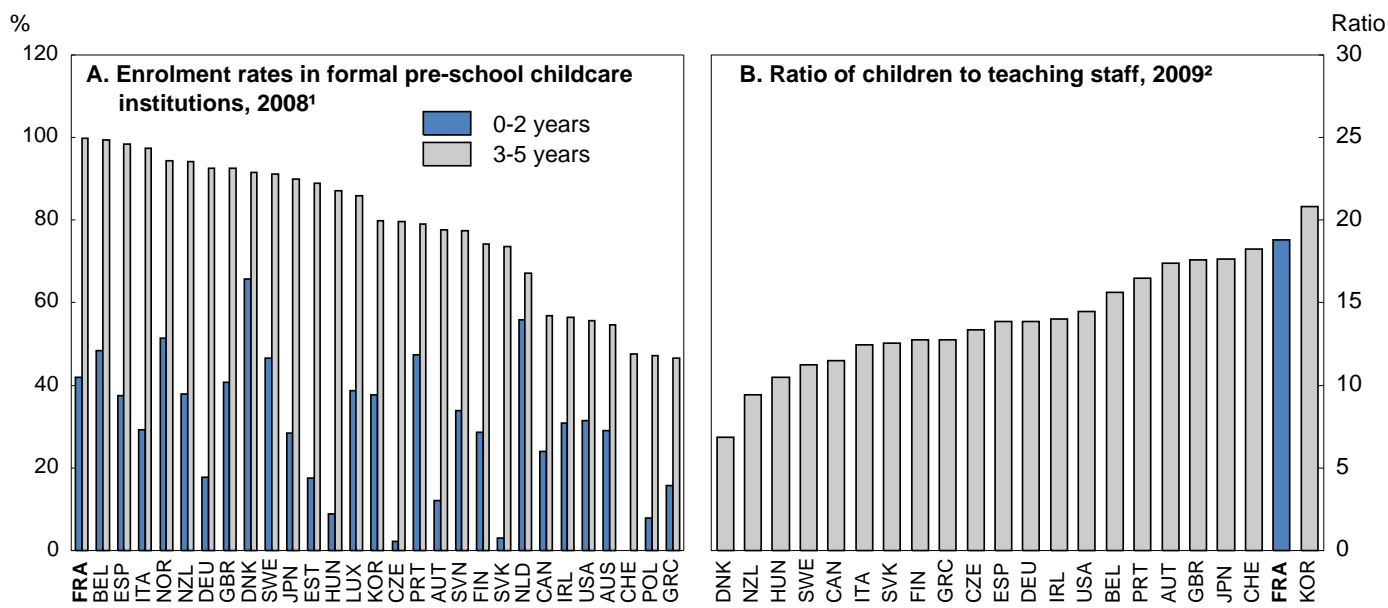

1. Enrolment rates are given in full-time equivalents.

2. Average for $0-3$ year-olds.

Source: OECD Family database.

The system as it stands now has a potentially strong redistributive element. Means-tested support for private pre-school child care and income-based fees in nurseries certainly favour the less affluent. In addition, there is some overlap between the CLCA, the means-tested benefits relating to the start of the school year (allocation de rentrée scolaire) and a young-child allowance for dual-career families (allocation de base de la prestation d'accueil du jeune enfant, PAJE). Furthermore, annual income caps vary to a large extent across different measures: about EUR 49000 for a single-earner couple with three children for the birth allowance and PAJE, EUR 35000 for the complementary benefit related to the third child, EUR 34000 for the school starting allowance and EUR 27000 for the direct subsidies of private pre-school childcare.

\section{Housing subsidies should be better integrated with the rest of the transfer system}

Amongst OECD countries, France spends a relatively large amount of its GDP on direct housing subsidies (Figure 15).The relevant transfers are the personalised housing support (aide personnalisée au logement, APL), the social housing benefit (allocation de logement social, ALS) and the family housing benefit (allocation de logement familial, ALF), together worth around EUR 16 billion a year and covering roughly 6 million households. They can lower either the rent or the monthly reimbursement of first-home buyers. APL supports low-income families and is paid directly to the landlord or to the bank (in the case of mortgage repayments). The landlord has to sign an agreement with the State. He or she gets special tax treatment but has to respect a rent ceiling. ALF can be used by families with children or young couples who do not qualify for APL. ALS is designed for low-income individuals who cannot benefit from APL and ALF. The benefits are means-tested: eligibility depends on household income and the working situation of its members but also the composition of the household and the location of the dwelling. Not only is the system very complicated, which makes it difficult for potential recipients to gain an overview and increases the administrative burden (all three benefits are administered by the Caisses d'allocations familiales, CAF), but it also has some serious drawbacks. First, means-testing is based on income reported two years before the application. This is too long a delay: potential beneficiaries might have higher income 
or become unemployed in the meantime. Second, the amount of support is a function of the rent below a certain fixed amount, which is akin to making the subsidy vary with the size of the flat. It would be better to have a fixed amount and leave the decision to the tenants whether they want to have a smaller flat and keep some of the money or take a bigger dwelling and have a higher out-of-pocket payment. Finally, according to HCF (2012), the income thresholds for means-testing have not been fully adjusted for higher market prices, which has reduced the redistributive impact of the system.

Figure 15. Public spending on housing benefits in OECD countries, 2009

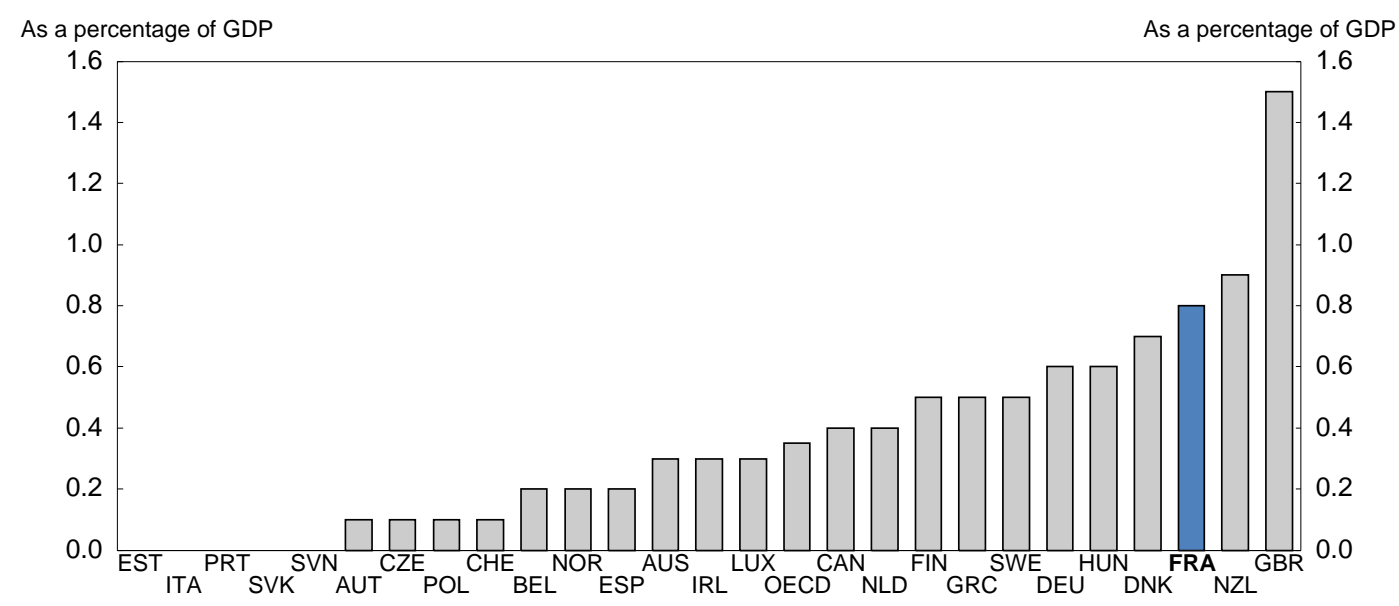

Source: OECD, Social Expenditure (SOCX) database.

The complexity of the financing side does not enhance transparency either. ALS and APL are financed by FNAL (Fonds national d'aides au logement), whereas the financing of ALF is provided by FNPF (Fonds national des prestations familiales). These funds are fed by central government transfers and employer SSCs. Indeed, businesses with more than 20 employees are required to pay $0.95 \%$ of their wage bill as a contribution (which sums to EUR 4 billion, given various exemptions). Roughly half of that goes to FNAL; the rest finances subsidies for first-time homebuyers and improvements to the private housing stock, expanding the rental housing supply, subsidies for relocating workers and funding for national policies, in the realm of urban renewal in particular.

Public support to housing goes well beyond direct subsidies. Various tax breaks violate tax neutrality and bias investment decisions and should therefore be phased out. Social housing, which in principle can be an important element of income redistribution, enjoys generous tax breaks, direct government subsidies and soft loans. While targeting has improved over time, the last Survey pointed to a number of weaknesses: i) the funding through special subsidised savings vehicles potentially distorts saving and investment decisions at the macroeconomic level; ii) social housing operators are too fragmented to exploit economies of scale and do a poor job of targeting needy neighbourhoods; iii) rents depend on past funding costs and, to a variable extent depending on the area, are unrelated to market rents; $i v)$ tenant turnover is very low; and $v$ ) a part of social housing benefits well-to-do households, which reduces redistributive effects. Improvement on these points would substantially raise the system's cost effectiveness.

\section{Old-age pension complexity should be reduced to facilitate necessary systemic reforms}

The French old-age pension system has a highly complicated structure with around 40 compulsory schemes with different eligibility criteria and pension benefits. Simplifying this complex structure is essential to facilitate transparency for employees who switch sectors and pension regimes over their careers, and most importantly, to increase fairness by reducing pension privileges of those enrolled in 
special pension schemes. Such heightened transparency could also facilitate achievement of financial equilibrium in the system. A system based on points or notional accounts is probably the solution that would offer the most operational flexibility.

Special pension regimes (including for the civil service) cover almost 4 million pensioners, essentially former civil servants, employees of state-owned companies and those in some specific sectors (miners, notaries and seamen), and pay annual benefits amounting to $3.5 \%$ of GDP. These regimes tend to offer more generous retirement conditions than the general scheme. Specific groups of civil servants in "active" service, including military personnel, policemen, firemen and prison guards, and in dirty jobs such as sewermen, can retire before the legal retirement rate and receive a pension after a shorter minimum contribution period (Table 8). Employees of the electricity and gas sectors, railway workers and employees of the Paris public transport company enjoy similarly favourable retirement conditions. The rules to calculate pension benefits for civil servants are so different from those in the private sector that it is difficult to have an overall idea about which scheme provides higher pensions. Overall, no reliable information is available about the costs of the special regimes. But one pre-condition of EDF/GDF being listed on the stock exchange in 2005 was the incorporation of its pension regime in the general scheme. Because the eligibility criteria were left unchanged, the State had to pay a compensation of about $0.5 \%$ of GDP to the national pension insurance fund (CNAV), an amount corresponding to the net present value of future pension payments due to its special conditions.

Table 8. Major special pension regimes in 2009

\begin{tabular}{|c|c|c|c|}
\hline & $\begin{array}{l}\text { Number } \\
\text { of retirees } \\
\text { (thousand) }\end{array}$ & $\begin{array}{l}\text { Pension benefits paid } \\
\text { (EUR billion } \\
\text { per annum) }\end{array}$ & Minimum retirement age \\
\hline \multicolumn{4}{|l|}{ Civil servants } \\
\hline Central government & 1590 & 41.6 & $\begin{array}{l}5 \text { years less than in the general system for } \\
\text { policemen, prison guards }\end{array}$ \\
\hline Army & 499 & & After 15 or 25 years of contribution \\
\hline $\begin{array}{l}\text { Local governments } \\
\text { (CNRACL) }\end{array}$ & 927 & 12.0 & $\begin{array}{l}5 \text { years less than in the general system for firemen, } \\
\text { policemen and } 10 \text { years less for specific categories } \\
\text { (e.g. sewermen) }\end{array}$ \\
\hline $\begin{array}{l}\text { Gas and electricity industry } \\
\text { (CNIEG) }\end{array}$ & 152 & 3.8 & \\
\hline Railways (CRPSNCF) & 284 & 5.1 & $\begin{array}{l}10 \text { years less for "rolling" employees and } 5 \text { years } \\
\text { less for the rest }\end{array}$ \\
\hline $\begin{array}{l}\text { Paris transport company } \\
\text { (CRPRATP) }\end{array}$ & 41 & 0.9 & \\
\hline $\begin{array}{l}\text { Industrial workers of public } \\
\text { companies (FSPOIE) }\end{array}$ & 62 & 1.5 & 5 years less for specific groups (service actif) \\
\hline $\begin{array}{l}\text { Bailiffs and notaries } \\
\text { (CRPCEN) }\end{array}$ & 65 & 0.7 & \\
\hline Seamen (ENIM) & 73 & 1.1 & 10 years less in the case of 25 years of contribution \\
\hline Miners (CANSSM) & 183 & 1.7 & 50 years for pit workers \\
\hline Churches (CAVIMAC) & 57 & 0.2 & \\
\hline Banque de France & 12 & 0.4 & \\
\hline Opera de Paris & 2 & 0.02 & \\
\hline Comédie française & 2 & 0.005 & \\
\hline Tobacco industry (SEITA) & 2 & 0.2 & \\
\hline $\begin{array}{l}\text { Port autonome de } \\
\text { Strasbourg }\end{array}$ & 2 & & \\
\hline Total & 3953 & 69.2 & \\
\hline
\end{tabular}

Source: Bureau des régimes spéciaux, Direction de la sécurité sociale. 
While France's public spending on old-age pensions is among the highest in the OECD relative to GDP, it is projected to increase only at a slow pace, by a further 0.5 percentage point of GDP by 2060 (European Commission, 2012). The 2010 pension reform aimed to ease pension spending obligations by progressively extending the minimum legal retirement age from 60 to 62 years and the retirement age to receive a full pension from 65 to 67 years by 2018 (which was subsequently brought forward to 2017 as part of fiscal consolidation). Under the 2003 Fillon reform, the government may change, by decree, the minimum contribution period, using expert opinions regarding changes in life expectancy at age 60 . Accordingly, the minimum contribution period needed for a full pension, which was 40 years at the time of the reform, was increased to 41.5 years for people born in 1955 or later. This is an important step towards long-term sustainability. However, the link between gains in life expectancy and the contribution period conferring entitlement to full pension benefits should be rendered fully automatic, such as in Latvia, Poland, Sweden and Norway (European Commission, 2012), thereby removing the possibility of any government interference. Scheme participants who have not contributed long enough to have a full pension are penalised by $1.25 \%$ per missing quarter on the pension payment. However, whatever the number of years worked, everybody receives a full pension when retiring at 67 , without any penalty but still proportional to the contribution period. The government's decision in June 2012 to reduce the minimum retirement age to 60 years for those who have reached the contribution period giving the right to a full pension increases fairness as they were unduly penalised by the rise in the minimum retirement age to 62 years. At the same time, as this change could impose an annual financial burden of EUR 1.1 billion in the short run and almost EUR 3 billion in 2017 on the pension system and hence public finances, the government decided to increase pension contributions. Overall, maintaining 62 as the minimum legal retirement age and providing long-career workers a bonus for extra years worked would have been preferable. According to a recent report by the Pension Advisory Board (Conseil d'Orientation des Retraites, 2013), under the best of circumstances, the pension system's balance can be restored only in the long term (by the early 2040s in a best-case scenario). However, under a number of long-term macroeconomic scenarios, the pension system's deficit would persist until 2060. Between 2012 and 2040, the accumulated debt of the pension system would amount to between 15 and $50 \%$ of GDP. Consequently, additional adjustments to the pension system's parameters will be needed quickly to reach financial balance.

Achieving actuarial fairness and neutrality would help maintain the pension system's long-term sustainability. An actuarially fair system would ensure, in a broader sense, that expected pension benefits would be directly linked to pension contributions paid over the working lifetime. According to a narrow definition of actuarial fairness at the individual level, the net present value of lifetime contributions and the net present value of lifetime benefits should be equal (Queisser and Whitehouse, 2006). But there is a trade-off between actuarial fairness and a potential desire to reduce income inequality in the pension system through redistribution, which would reduce fairness at the individual level. In France, pension benefits in the general system are determined on the basis of the best 25 years' income over one's career. The full career should be taken into account to approach actuarial fairness. Actuarial neutrality means that working longer is not penalised and that marginal incentives to continue working are the same at all ages (which in theory would imply that bonuses and penalties should vary according to age). The bonus and penalty applied in the French system seem to broadly achieve this.

The 2010 reform also scheduled discussions to take place in 2013 about achieving long-term balance in the pension system. A universal pension system based on points or with individual notional accounts would not only make it easier to enforce actuarial neutrality and fairness, it would also provide the flexibility to achieve financial balance as population ageing proceeds. In addition, it would make the system more transparent for the insured. Points can be converted into pension payments using an aggregate conversion coefficient, which accounts for life expectancy at the time of retirement, demographic projections and projected receipts and outlays of the pension system. The conversion coefficient can be set in a way to balance outlays with receipts. Such a system is well equipped to deal with forthcoming population ageing insofar as the conversion factor can be revised during pensioners' lifetimes. But this 
flexibility would come at the expense of reducing intergenerational equity. A points-based system could also have redistributive elements, which would come at a cost of distorting actuarial fairness at the individual level.

Old-age poverty rates in France are below the OECD average. Pension systems in some countries, including the Czech Republic, New Zealand and the Netherlands, generate extremely low old-age poverty rates, well below those observed in the general population, and almost no pension inequality between men and women. In France, the poverty rate for pensioners is comparable to that of workers and lower than for the whole population; however, older women tend to fall much more often below the poverty line than their male counterparts (Figure 16). Indeed, the French system reduces pension inequality to a large degree: gross and net pension replacement rates are considerably lower for high-income earners than for low-income individuals (OECD, 2011c). Retirement income is redistributed via several channels. Some measures aim to top up low pension benefits. They include a minimum pension paid by the general regime (minimum contributif) and a means-tested minimum income benefit (minimum vieillesse), which is paid mostly to people with low-incomes (OECD, 2011c). Other measures seek to compensate for shorter careers to achieve the minimum contribution period needed for a full pension: periods of unemployment during which unemployment benefits are received and time spent in sickness and invalidity are taken into account for benefit determination. On the other hand, Aubert and Bachelet (2012) show empirically that taking the best 25 years as a basis for the calculation of pension benefits amplifies pension income inequality because low-income individuals tend to have shorter careers than those with high earnings.

Figure 16. Old-age poverty rates in OECD countries, mid 2000s

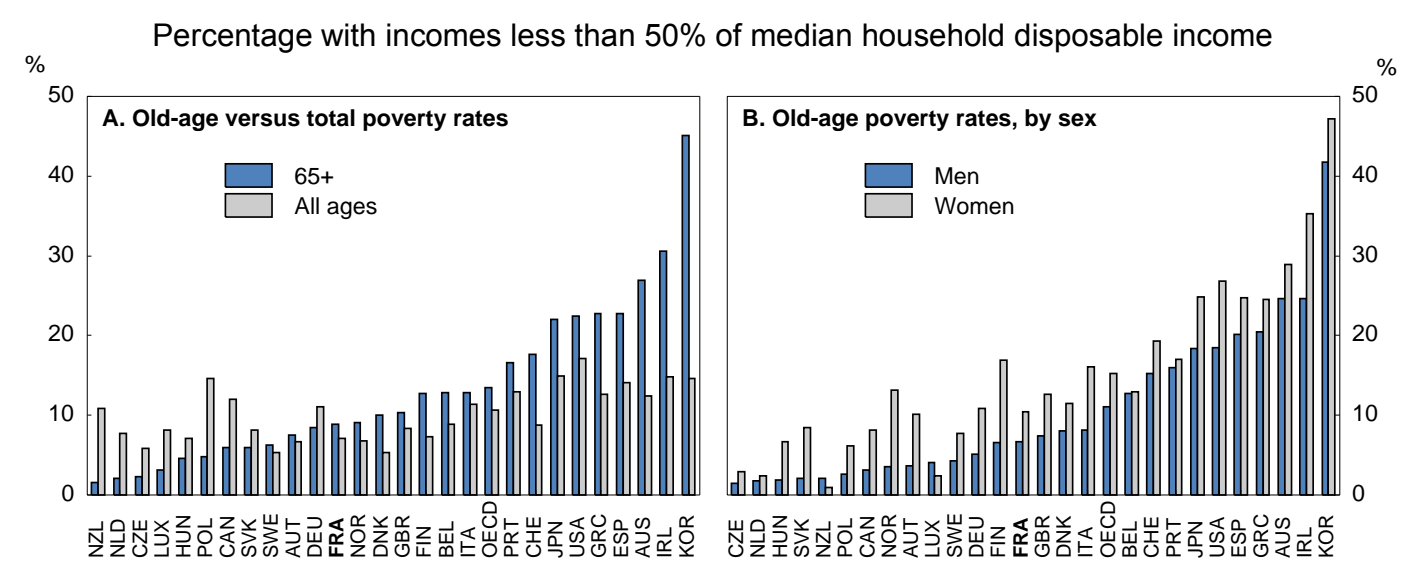

Source: OECD (2011), Pensions at a Glance.

\section{Survivors' pensions lower female participation and discriminate against private-sector pensioners and unmarried people}

Survivors' pension benefits account for almost $2 \%$ of France's GDP, which is higher than the OECD average (Figure 10, Panel $\mathrm{C}$ above). This system should internalise the costs of death within the family (James, 2009). Moreover, they imply redistribution from women who work to those who stay at home and from singles and two-earner families to single-earner families, penalising second-earners' labour market participation. Survivors' pensions are indeed generous in France because they do not account for the cost of such additional (life) insurance. Employees should be able to opt for survivors' pensions, as in Sweden, in which case they would either pay higher contribution rates or receive lower pension benefits (Whitehouse, 2013). 
There is also some disparity between eligibility criteria for survivors' pensions for private- and public-sector employees. The spouse of a private-sector pensioner can claim survivors' benefits if he or she is older than 55. The survivor benefit cannot exceed $60 \%$ of the pension of the deceased, is means tested and has an upper limit. By contrast, a spouse of a public-sector retiree can receive survivor benefits without any restrictions regarding the survivor's age and income (but the survivor benefit rate may not exceed $50 \%$ ). The survivor benefit is increased by half of the $10 \%$ bonus received after three or more children. Overall, the asymmetric treatment of private- and public-sector pensioners should be phased out.

\section{In-kind benefits: health-care and education services}

In-kind benefits provided through public (health and education) services reduce income inequality in France. Their redistributive impact depends on the volume of those services and the targeting of the benefits. Health-care services make a substantial contribution to income redistribution because of their sheer mass: public health-care expenditures account for 9\% of French GDP and cover $80 \%$ of total health-care spending. The same amount of public services, allocated as a first approximation in equal portions to all households increases household disposable incomes more the lower the household is in the income distribution. INSEE estimates suggest that a few years ago public in-kind benefits from health-care services accounted for over 35\% of the reduction in income inequality (Marical, 2007; Amar et al., 2008).

Redistribution occurs along the following dimensions: gender, age and income. Women of childbearing age tend to consume more health services than men of the same age. Children and elderly people make more use of public health-care services than other demographic groups, leading to horizontal redistribution between families of different size and between different generations. Intergenerational redistribution is amplified by the fact that old people tend to be situated in the lower part of the income distribution. When age and gender are controlled for, low-income individuals consume more hospital services and primary care, the reimbursement rates for which are high, in contrast to dental and specialist care, of which wealthier people avail themselves more often. The fact that public health insurance covers the bulk of hospital and primary care, combined with socialised funding, results in redistribution to those least well-off through the health-care system.

Similarly to public health-care services, public spending on education has a massive impact on income redistribution, when calculated on the basis of average costs per person enrolled in public educational institutions. In the middle of the $2000 \mathrm{~s}$, the contribution of public educational services to redistribution was 30\% (Amar et al., 2008), because they absorb about 5\% of French GDP and also because the monetary value of these in-kind transfers diminishes as household income rises. But redistribution is uneven depending on the type of educational service. Transfers related to pre-school (excluding nurseries) and primary education benefit most the least affluent households, which tend to be single-earner families with more children. But the value of in-kind benefits relating to secondary education increases for more wealthy households, given that children from these households opt more often for general secondary schools, at which attendance is longer and more costly than at vocational schools utilised by poorer families (Allègre et al., 2010). Finally, there is a U-shaped pattern for tertiary education because poor student households receive important financial aid and because the children of the most affluent households have a higher propensity to attend.

Nevertheless, using current spending on education as a measure of income redistribution may be flawed if present differences in income are due to past expenditures on education. In any case, spending does not necessarily reflect the quality of education, which may vary a great deal across locations. Also, whether a given amount of public spending on education reduces or increases income inequality depends to a large extent on the returns to education: in fact, socio-economic background and social capital have a much larger impact than actual public spending (Allègre et al., 2010). Rather than incorporating the monetary value of public educational services into the definition of income, a more useful benchmark 
would be to see the extent to which public education reduces the impact of parental socio-economic status on educational outcomes and future income and improves inter-generational social mobility. A related area is the training of employees, which costs up to $1.5 \%$ of GDP, financed partly by a tax levied on employers' wage bill. It is not only a very complex system and of low quality but also magnifies inequality by favouring those who need it least (Cahuc et al., 2011).

\section{Box 2. Recommendations for improving the efficiency and equity of tax and transfer policies}

\section{Improve neutrality of taxation of across asset classes and within specific taxes}

- $\quad$ Reduce the complexity and enhance the stability of the tax system.

- Broaden tax bases by phasing out costly tax expenditures, rather than increasing statutory rates. Reform the taxation of saving products by imposing similar tax treatment for all products. Explore the possibility of shifting taxes from nominal to real returns. Streamline the taxation of dividends.

- Turn the taxe foncière into the equivalent of a tax on imputed rents by regularly updating the cadastral/rental values and phase out taxes on actual rents. Align the taxation of capital gains on housing with that applied to other assets, though the payment of capital gains taxes on housing should be deferred until the owner's death. Cut transaction taxes on the purchase of property.

- Tax bequests and gifts based on the amount received over one's lifetime, no matter the source.

- Gradually phase out reduced VAT rates, and compensate the poor if necessary via means-tested annual payments to achieve distributional objectives in a more cost-efficient way.

- $\quad$ Equalise implicit and explicit carbon prices across emissions sources, make abatement costs due to feed-in tariffs more homogenous for renewables, and alter the bonus-penalty system applied to new car purchases so as to eliminate bonuses and enhance cost effectiveness.

Tax system

- Increase CSG on pension income, introduce pensioner contributions for health care and simplify the current system of minimum pensions by eliminating tax breaks for pensioners and, if needed, raising the minimum pension.

- $\quad$ Adopt individual-based personal income taxation.

\section{Transfers}

- $\quad$ Simplify all social benefits substantially. Merge activity RSA and the in-work tax credit (prime pour l'emploi, PPE).

- Abolish all of the special provisions of unemployment benefit schemes applicable to seniors. Introduce degressivity into allowances paid during periods of unemployment. Strengthen the linkages between compensation, job search and participation in back-to-work measures that are more effective.

- Impose stricter job-search requirements on social benefit recipients, and introduce activation policies for disability pensions. Avoid potential benefit substitution by firmly enforcing access conditions for disability pensions.

- $\quad$ Delay retirement by reducing the maximum duration of unemployment benefits of older workers and by phasing out the special solidarity allowance (ASS). Internalise at the individual level the costs of survivors' pensions in old-age pension benefits. Render the link between gains in life expectancy and the pension eligibility age fully automatic. Eliminate special occupational pension schemes, and introduce a universal pension system based on points or notional accounts.

- Increase incentives for low-skilled women to return to the labour market after the birth of their children by shortening the duration of the parental leave allowance and by increasing the supply of places in public nurseries. 


\section{Bibliography}

Alduy, J-P. (2011), "Rapport d'information fait au nom de la mission commune d'information relative à Pôle emploi", Sénat, No. 713.

Allègre, G., T. Mélonio and X. Timbeau (2010), "Dépenses publiques d'éducation et inégalités : une perspective de cycle de vie", Document de travail de l'OFCE, No. 2010-06.

Amar, E., M. Beffy, F. Marical and E. Raynaud (2008), "Les services publics de santé, éducation et logement contribuent deux fois plus que les transferts monétaires à la réduction des inégalités de niveau de vie", INSEE, France, portrait social-édition 2008.

Atkinson, A.B and J.E. Stiglitz (1976), "The Design of Tax Structure: Direct versus Indirect Taxation", Journal of Public Economics, Vol. 6, No. 1-2, 55-75.

Aubert, P. and M. Bachelet (2012), "Disparités de montant de pension et redistribution dans le système de retraite français", INSEE, série des documents de travail de la Direction des Études et Synthèses Économiques, G 2012/06.

Behaghel, L., B. Crépon and M. Gurgand (2012), "Private and public provision of counselling to job-seekers: evidence from a large controlled experiment”, IZA Discussion Papers, No. 6518.

Bonnefoy, V., S. Buffeteau and M-C. Cazenave (2009), "De la prime pour l'emploi au revenu de solidarité active : un déplacement de la cible au profit des travailleurs pauvres". INSEE, France, portrait social-edition 2009.

Bourgeois C. et C. Tavan (2009), "Le Revenu de Solidarité Active : principes de construction et effets attendus", Lettre Trésor-Éco, No. 61, July.

Bourguignon, F. (2011), Comité national d'évaluation du rSa, Rapport final, December.

Bozio, A. et al. (2012), Fiscalité et redistribution en France : 1997-2012, Institut des Politiques Publiques, March.

Cahuc, P., G. Cette and A. Zylberberg (2008), Salaire minimum et bas revenus: comment concilier justice sociale et efficacité économique?, Conseil d'Analyse Économique.

Cahuc, P., M. Ferracci and A. Zylberberg (2011), La formation professionnelle des adultes: pour en finir avec les réformes inabouties, Institut Montaigne, October.

Carbonnier, C. (2007), "L'impact de la fiscalité sur la participation des conjoints au marché du travail", Documents de travail de la DGTPE, No. 2007-05. 
Cazenave, M-C., J. Duval, A. Eidelman, F. Langumier and A. Vicard (2011), "La redistribution: état des lieux en 2010 et évolution depuis vingt ans", INSEE, France, portrait social-édition 2011, Paris.

Chaput, H., K.-H. Luu Kim, L. Salembier and J. Solard (2011), "Les inégalités de patrimoine s'accroissent entre 2004 et 2010”, INSEE Première, No. 1380.

CNFPT (2010), La formation des demandeurs d'emploi, May http://www.cnfpt.fr/documents/042011/280411181346FicheRepresFormationDE.pdf

Conseil d'Orientation des Retraites (2013), Retraites : un état des lieux du système français, Twelfth report, adopted on 22 January 2013.

Conseil des Prélèvements Obligatoires (2009), Les prélèvements obligatoires des entreprises dans une économie globalisée, October.

Cour des Comptes (2012), La sécurité sociale, Rapport 2012 sur l'application des lois de financement de la sécurité sociale, September, Paris.

CPO (2010), Entreprise et niches fiscales et sociales : des dispositifs dérogatoires nombreux, October, Paris.

D'Addio, C.A. and M. Mira d'Ercole (2005), "Trends and Determinants of Fertility Rates: The Role of Policies", OECD Social, Employment and Migration Working Papers, No 27.

DARES (2012), "Quand les demandeurs d'emploi ne sont pas couverts par le régime d'assurance chômage : les allocataire de l'ASS, de l'AER et les demandeurs d'emploi n'ayant pas de droit ouvert en 2010", DARES Analysis No. 20.

DARES - Pôle empoi (2013), "L'accompagnement renforcé des demandeurs d'emploi : évaluation du recours aux opérateurs privés par Pôle emploi de 2009 à 2011”, Synthèse.Eval No. 03, January.

Denk, O. (2012), "Tax Reform in Norway: A Focus on Capital Taxation", OECD Economics Department Working Papers, No. 950, OECD Publishing.

Dormont, B., D. Fougère and A. Prieto (2001), "L'effet de l'allocation unique dégressive sur la reprise de l'emploi", Economie et Statistique, 343, 3-28.

Duval, J., A. Eidelman, F. Langumier and T. Leibowicz (2012), "La redistribution: état des lieux en 2011", INSEE, France, portrait social - 2012 edition, Paris.

Ernst \& Young (2011), The 2011 global executive: individual tax, social security and immigration, London.

Givord, P. et X. d'Haultfoeuille (2012), "Le bonus/malus écologique: éléments d'évaluation", INSEE Analyses No. 3, January 2012.

European Commission (2012), "The 2012 Ageing Report: Economic and budgetary projections for the 27 EU member States (2010-2060)", European Economy 2012/2 (provisional version), Brussels.

HCF (2012), Familles et logement, Avis, adopté par consensus par le Haut Conseil de la Famille lors de la séance du 10 mai 2012. 
Hoeller, P., I. Joumard, M. Pisu and D. Bloch (2012), "Less Income Inequality and More Growth - Are They Compatible? Part 1. Mapping Income Inequality Across the OECD", OECD Economics Department Working Papers, No. 924, OECD Publishing.

Inspection Générale des Finances (2011), Étude comparative des effectifs des services publics de l'emploi en France, en Allemagne et au Royaume-Uni, Report No. 2010M06402.

IZA (2010), "The mobility and integration of people with disabilities into the labour market", IZA Research Report, No. 29.

James, E. (2009), "Rethinking Survivor Benefits", World Bank, Social Protection and Labor Discussion Paper, No. 928.

Jaumotte, F. (2003), "Female labour force participation: Past trends and main determinants in OECD countries", OECD Working Documents of the Economics Directorate, No. 376.

Kleven, H., C. Landais and E. Saez (2010), “Taxation and International Migration of Superstars: Evidence from the European Footbass Market”, NBER Working Papers, No. 16545.

Koske, I., J-M. Fournier and I. Wanner (2012), "Less Income Inequality and More Growth - Are They Compatible? Part 2. The Distribution of Labour Income", OECD Economics Department Working Papers, No. 925, OECD Publishing.

Luci, A. and O. Thévenon (2012), "The impact of family policy packages on fertility trends in developed countries", Institut National d'Études Démographiques (INED), Working Papers No. 174.

Marical, F. (2007), "En quoi la prise en compte des transferts liés à la santé modifie-t-elle l'appréciation du niveau de vie", INSEE, France, portrait social - édition 2007.

Mirrlees Review (2011), Tax by design, Institute for Fiscal Studies, London.

OECD (2005), Economic Surveys: Sweden, OECD Publishing.

OECD (2009), Economic Surveys: France, OECD Publishing.

OECD (2010), Sickness, disability and work: breaking the barriers. A synthesis of findings across OECD countries, OECD Publishing.

OECD (2011a), Divided We Stand, OECD Publishing.

OECD (2011b), Taxation and Employment, OECD Tax Policies Studies, No. 21, OECD Publishing.

OECD (2011c), Pensions at a Glance 2011, OECD Publishing.

OECD (2011d), Taxing wages: 2010-2011, Special feature: trends in personal income tax and social security contribution schedules, OECD Publishing.

OECD (2011e), Economic Surveys: France, OECD Publishing, March.

OECD (2012a), Settling In: OECD indicators on the integration of immigrants 2012, OECD Publishing.

OECD (2012b), Activating Jobseekers: How Australia Does It, OECD Publishing. 
OECD-ILO (2011), "France: A simplified social benefits system", G20 Country Policy Briefs. http://www.oecd.org/els/48724021.pdf

Ourliac, B. and C. Nouveau (2012), "Les allègements de cotisation sociales patronales sur les bas salaires en France de 1993 à 2009”, DARES, Document d'études, No. 169, February.

Piketty, T., E. Saez and S. Stantcheva (2011), "Optimal taxation of top labour incomes: A tale of three elasticities”, NBER Working Papers, No. 17616.

Pôle emploi (2012), “Un nouvel indicateur pour les portefeuilles de demandeurs d'emploi”, Press release, 22 June 2012.

Prieto, A (2000), "L'impact de la dégressivité des allocations chômage sur le taux de reprise de l'emploi", Revue Economique, 51(3), 523-534.

Queisser, M. and E.R. Whitehouse (2006), "Neutral or fair?: actuarial concepts and pension-system design", OECD Social, Employment and Migration Working Paper, Number 40, OECD Publishing.

Røed, K. and L. Westlie (2012), "Unemployment insurance in welfare states: the impacts of soft duration constraints", Journal of the European Economic Association, Vol. 10, No. 3, 518-554.

Ruiz, N. and A. Trannoy (2008), "Le caractère régressif des taxes indirectes : les enseignements d'un modèle de microsimulation", Economie et Statistique, No. 413, 21-46.

Saez, E., J. Slemrod and S.H. Giertz (2012), "The elasticity of taxable income with respect to marginal tax rates: a critical review", Journal of Economic Literature 50(1), 3-50.

Simula, L. and A. Trannoy (2009), "Optimal income tax under the threat of migration by top-income earners", Uppsala Center for Fiscal Studies Working Paper, No. 2009/8.

Standard \& Poor's $\quad$ (2012), RatingsDirect:Unedic, http://www.unedic.org/sites/default/files/ratings_direct_analysis_unedic_sp_2012.pdf

27 August.

Whitehouse, E.R. (2013), "Adequacy and sustainability of pension systems: evidence from Europe", OECD Social, Employment and Migration Working Paper, forthcoming. 
ECO/WKP(2013)30

\section{WORKING PAPERS}

The full series of Economics Department Working Papers can be consulted at www.oecd.org/eco/workingpapers/

1037. Income inequality and poverty in Colombia. Part 2. The redistributive impact of taxes and transfers

(March 2013) by Isabelle Joumard and Juliana Londoño Vélez

1036. Income inequality and poverty in Colombia. Part 1. The role of the labour market

(March 2013) by Isabelle Joumard and Juliana Londoño Vélez

1035. Policy options to durably resolve euro area imbalances

(March 2013) by Yvan Guillemette and Dave Turner

1034. Labour market, welfare reform and inequality in the United Kingdom

(March 2013) by Christophe André, Clara Garcia, Giulia Giupponi and Jon Kristian Pareliussen

1033. Work incentives and Universal Credit - reform of the benefit system in the United Kingdom (March 2013) by Jon Kristian Pareliussen

1032. Strengthening social cohesion in Luxembourg: making efficiency and equity go hand in hand

(March 2013) by Jean-Marc Fournier and Clara Garcia

1031. The price of oil - Will it start rising again?

(March 2013) by Jean-Marc Fournier, Isabell Koske, Isabelle Wanner and Vera Zipperer

1030. The system of revenue sharing and fiscal transfers in China

(February 2013) by Xiao Wang and Richard Herd

1029. The declining competitiveness of French firms reflects a generalised supply-side problem (February 2013) by Hervé Boulhol and Patrizio Sicari

1028. Do the overall level and dispersion of socio-economic background measures explain France's gap in PISA scores?

(February 2013) by Hervé Boulhol and Patrizio Sicari

1027. Labour market performance by age groups: a focus on France

(February 2013) by Hervé Boulhol and Patrizio Sicari

1026. Moving towards a single labour contract: pros, cons and mixed feelings

(February 2013) by Nicolas Lepage-Saucier, Juliette Schleich and Etienne Wasmer

1025. Boosting productivity in Australia

(January 2013) by Vassiliki Koutsogeorgopoulou and Omar Barbiero

1024. Housing, financial and capital taxation policies to ensure robust growth in Sweden (January 2013) by Müge Adalet McGowan

1023. Labour market and social policies to foster more inclusive growth in Sweden

(January 2013) by Stéphanie Jamet, Thomas Chalaux and Vincent Koen 
ECO/WKP(2013)30

1022. Educational attainment and labour market outcomes in South Africa, 1994-2010 (January 2013) by Nicola Branson and Murray Leibbrandt

1021. Education quality and labour market outcomes in South Africa (January 2013) by Nicola Branson and Murray Leibbrandt

1020. Do policies that reduce unemployment raise its volatility? Evidence from OECD countries (January 2013) by Alain de Serres and Fabrice Murtin

1019. Slovakia: A catching up euro area member in and out of the crisis (January 2013) by Jarko Fidrmuc, Caroline Klein, Robert Price and Andreas Wörgötter

1018. Improving the fiscal framework to enhance growth in an era of fiscal consolidation in Slovakia (January 2013) by Caroline Klein, Robert Price and Andreas Wörgötter

1017. Investing efficiently in education and active labour market policies in Slovakia (January 2013) by Caroline Klein

1016. The performance of road transport infrastructure and its links to policies (January 2013) by Henrik Braconier, Mauro Pisu and Debra Bloch

1015. The US labour market recovery following the great recession (January 2013) by Wendy Dunn

1014. Why do Russian firms use fixed-term and agency work contracts? (December 2012) by Larisa Smirnykh and Andreas Wörgötter

1013. The Equity implications of fiscal consolidation (December 2012) by Lukasz Rawdanowicz, Eckhard Wurzel and Ane Kathrine Christensen

1012. The Dutch labour market: preparing for the future (December 2012) by Mathijs Gerritsen and Jens Høj

1011. Reforming policies for the business sector to harvest the benefits of globalisation in the Netherlands

(December 2012) by Mathijs Gerritsen and Jens Høj

1010. Health care reform and long-term care in the Netherlands (December 2012) by Erik Schut, Stéphane Sorbe and Jens Høj

1009. Enhancing the inclusiveness of the labour market in Belgium (December 2012) by Jens Høj

1008. Reducing poverty in Estonia through activation and better targeting (December 2012) by Sarah Flèche and Artur Radziwill

1007. Matching skills and jobs in Estonia (December 2012) by Lilas Demmou 